Supporting Information

\title{
Biodegradable Upconversion Nanoparticles Induce Pyroptosis for Cancer Immunotherapy
}

Binbin Ding, ${ }^{\dagger}$ Jiyao Sheng, ${ }^{\S}$ Pan Zheng, ${ }^{+\perp}$ Chunxia Li, ${ }^{\perp}$ Dong Li, " Ziyong Cheng, ${ }^{\dagger, t}$ Ping 'an Ma, ${ }^{*,+, t}$ and Jun Lin ${ }^{*,+, *}$

$\uparrow$ State Key Laboratory of Rare Earth Resource Utilization, Changchun Institute of Applied Chemistry, Chinese Academy of Sciences, Changchun, 130022, China

† University of Science and Technology of China, Hefei 230026, P. R. China

$\perp$ Institute of Frontier and Interdisciplinarity Science and Institute of Molecular Sciences and Engineering, Shandong University, Qingdao, 266237, China

$\S$ Department of Hepatobiliary and Pancreatic Surgery, The Second Hospital of Jilin University, Changchun, 130021, China

|| College of Basic Medical Sciences, Jilin University, Changchun, 130021, China 


\section{Experimental Section}

Chemicals. All chemical reagents were used directly without further purification. Zirconium (IV) acetylacetonate $\left(\mathrm{Zr}(\mathrm{acac})_{4}, 98 \%\right)$, ytterbium acetate tetrahydrate $\left(\mathrm{Yb}\left(\mathrm{CH}_{3} \mathrm{CO}_{2}\right)_{3} \bullet 4 \mathrm{H}_{2} \mathrm{O}, 99.9 \%\right)$, erbium acetate tetrahydrate $\left(\mathrm{Er}\left(\mathrm{CH}_{3} \mathrm{CO}_{2}\right)_{3} \bullet 4 \mathrm{H}_{2} \mathrm{O}, 99.99 \%\right)$, potassium hydroxide $(\mathrm{KOH}, 99.999 \%)$ and ammonium fluoride $\left(\mathrm{NH}_{4} \mathrm{~F}, \geq 99.99 \%\right)$ were purchased from Aladdin. Yttrium chloride $\left(\mathrm{YCl}_{3} \bullet\right.$ $\left.6 \mathrm{H}_{2} \mathrm{O}, 99.99 \%\right)$, ytterbium chloride $\left(\mathrm{YbCl}_{3} \bullet 6 \mathrm{H}_{2} \mathrm{O}, 99.99 \%\right)$ and erbium chloride $\left(\mathrm{ErCl}_{3} \bullet 6 \mathrm{H}_{2} \mathrm{O}\right.$, 99.99\%) were purchased from Beijing HWRK Chem Co. Ltd. Oleic acid (OA, 98\%) and 1-octadecene (ODE, 95\%) were purchased from Aldrich. Sodium hydroxide ( $\mathrm{NaOH}, 99 \%)$ was purchased from the Beijing Chemical Reagent Company.

Cell lines and animals. 4T1 and L929 cells were first cultured in Roswell Park Memorial Institute (RPMI) 1640 medium and Dulbecco's Modified Eagle's Medium (DMEM) supplemented with 10\% heat-inactivated fetal bovine serum (FBS, GIBCO), 100 units per $\mathrm{mL}$ of penicillin and 100 units per $\mathrm{mL}$ of streptomycin (Sigma) in an atmosphere of $5 \% \mathrm{CO}_{2}$ at $37{ }^{\circ} \mathrm{C}$, respectively. Female Balb/c mice (17-21 g) were purchased from the Center for Experimental Animals, Jilin University (Changchun, China). All mice were handled using the protocol approved by the Institutional Animal Care and Use Committee of Jilin University.

Synthesis of $\mathrm{K}_{3} \mathrm{ZrF}_{7}: 20 \% \mathrm{Yb}, \mathbf{2} \% \mathrm{Er}$ nanoparticles (ZrNPs). $114.1 \mathrm{mg}$ of $\mathrm{Zr}(\mathrm{acac})_{4}(0.234 \mathrm{mmol})$, $25.3 \mathrm{mg}$ of $\mathrm{Yb}\left(\mathrm{CH}_{3} \mathrm{CO}_{2}\right)_{3} \bullet 4 \mathrm{H}_{2} \mathrm{O}(0.06 \mathrm{mmol}), 2.5 \mathrm{mg}$ of $\mathrm{Er}\left(\mathrm{CH}_{3} \mathrm{CO}_{2}\right)_{3} \bullet 4 \mathrm{H}_{2} \mathrm{O}(0.006 \mathrm{mmol}), 5 \mathrm{~mL}$ of OA and $10 \mathrm{~mL}$ of ODE were added to a $150 \mathrm{~mL}$ three-necked flask. The solution was heated to $130{ }^{\circ} \mathrm{C}$ under stirring for $60 \mathrm{~min}$. After cooling to room temperature, $2 \mathrm{~mL}$ of methanol solution containing $101 \mathrm{mg}$ of $\mathrm{KOH}(1.8 \mathrm{mmol})$ and $5 \mathrm{~mL}$ of methanol solution containing $77.8 \mathrm{mg}$ of $\mathrm{NH}_{4} \mathrm{~F}(2.1 \mathrm{mmol})$ were added, respectively. Then the mixture was heated to $70{ }^{\circ} \mathrm{C}$ and stirred for $30 \mathrm{~min}$ to remove methanol. Next, the solution was placed under vacuum for $20 \mathrm{~min}$ and slowly heated to $305{ }^{\circ} \mathrm{C}$ and 
maintained for 40 min under nitrogen. The obtained ZrNPs were precipitated by adding $10 \mathrm{~mL}$ of ethanol and collected by centrifugation ( $8000 \mathrm{rpm}$ for $8 \mathrm{~min}$ ).

Synthesis of $\mathrm{NaYF}_{4}: 20 \% \mathrm{Yb}, 2 \% \mathrm{Er}$ nanoparticles (YNPs). Typically, $0.78 \mathrm{~mL}$ of $\mathrm{YCl}_{3}$ aqueous solution $(1 \mathrm{~mol} / \mathrm{L}), 0.20 \mathrm{~mL}$ of $\mathrm{YbCl}_{3}$ aqueous solution $(1 \mathrm{~mol} / \mathrm{L}), 0.20 \mathrm{~mL}$ of $\mathrm{ErCl}_{3}$ aqueous solution (0.1 mol/L), $6 \mathrm{~mL}$ of OA and $15 \mathrm{~mL}$ of ODE were added to a $150 \mathrm{~mL}$ three-necked flask. The solution was heated to $130{ }^{\circ} \mathrm{C}$ under stirring for $60 \mathrm{~min}$. After cooling to room temperature, $10 \mathrm{~mL}$ of methanol solution containing $100 \mathrm{mg}$ of $\mathrm{NaOH}(2.5 \mathrm{mmol})$ and $148.2 \mathrm{mg}$ of $\mathrm{NH}_{4} \mathrm{~F}(4 \mathrm{mmol})$ were added. Then the mixture was heated to $70{ }^{\circ} \mathrm{C}$ and stirred for $30 \mathrm{~min}$ to remove methanol. Next, the solution was placed under vacuum for $20 \mathrm{~min}$ and slowly heated to $300{ }^{\circ} \mathrm{C}$ and maintained for 90 min under nitrogen. The obtained YNPs were precipitated by adding $10 \mathrm{~mL}$ of ethanol and collected by centrifugation (8000 rpm for $8 \mathrm{~min})$.

Material characterization. The transmission electron microscopy (TEM) images of samples were obtained using a FEI Tecnai G2 S-Twin with a field emission gun operating at $200 \mathrm{kV}$. Their crystal structure was determined by $\mathrm{X}$-ray powder diffraction (Bruker) equipped with $\mathrm{Cu}-\mathrm{K} \alpha$ radiation $(\lambda=0.154 \mathrm{~nm})$. The X-ray photoelectron spectra (XPS) were taken on a VG ESCALAB MK II electron spectrometer using $\mathrm{Mg} \mathrm{K \alpha}(1200 \mathrm{eV})$ as the excitation source, putting the samples on silicon slice. Concentrations of $\mathrm{Zr}, \mathrm{K}$ and $\mathrm{F}$ were tested by inductively coupled plasma-mass spectrometer (ICPMS). UCL imaging was recorded on an in vivo Maestro whole-body imaging system equipped with an external $980 \mathrm{~nm}$ laser as the excitation source.

In vitro degradation testing. The obtained $\mathrm{ZrNPs}$ were dispersed into $12 \mathrm{~mL}$ of cyclohexane. Then $1 \mathrm{~mL}$ of ZrNPs cyclohexane solution was added into $2 \mathrm{~mL}$ of deionized water and the mixed solution was standing for different time $(0 \mathrm{~h}, 0.5 \mathrm{~h}, 1 \mathrm{~h}, 1.5 \mathrm{~h}, 3 \mathrm{~h}, 6 \mathrm{~h}, 12 \mathrm{~h}, 24 \mathrm{~h}$ and $48 \mathrm{~h})$. Finally, the cyclohexane solution and aqueous solution were collected for upconversion luminescence (UCL) and ions detections, respectively. The concentrations of $\mathrm{K}^{+}, \mathrm{F}^{-}$and $\mathrm{Zr}^{4+}$ ions were detected by ICP-MS. To 
further study the degradation of ZrNPs in the biologically-relevant environment, $0.5 \mathrm{~mL}$ of $\mathrm{ZrNPs}$ in DMSO $(100 \mathrm{mM})$ was added into $4 \mathrm{~mL}$ of RPMI 1640 medium and the mixed solution was standing at $37^{\circ} \mathrm{C}$. At different time points $(1 \mathrm{~h}, 2 \mathrm{~h}, 3 \mathrm{~h}, 6 \mathrm{~h}, 12 \mathrm{~h}, 24 \mathrm{~h}$ and $48 \mathrm{~h})$, the supernate was collected by centrifugation (10000 rpm for $5 \mathrm{~min}$ ) for ICP-MS detection.

Cellular uptake assay. To study the cell uptake mechanism of hydrophobic ZrNPs, 4T1 cells were seeded into 6-well plates at the density of $2 \times 10^{5}$ cells per well ( $1 \mathrm{~mL}$ of RPMI 1640 medium) and then incubated with $\mathrm{NaN}_{3}(120 \mathrm{mM})$ or chlorpromazine hydrochloride $(\mathrm{CPZ})\left(30 \mu \mathrm{g} \mathrm{mL} \mathrm{m}^{-1}\right)$ for $1 \mathrm{~h}$ at $37^{\circ} \mathrm{C}$. The cells were then washed with RPMI 1640 medium and incubated with ZrNPs $(5 \mu \mathrm{L}, 100$ $\mathrm{mM})$ for $4 \mathrm{~h}$. Simultaneously, 4T1 cells were treated with ZrNPs $(5 \mu \mathrm{L}, 100 \mathrm{mM})$ directly and then incubated at $37{ }^{\circ} \mathrm{C}$ for $1 \mathrm{~h}$ and $4 \mathrm{~h}$, respectively. After washing with PBS three times, the cells in all groups were lysed using cell lysis buffer $\left(2 \mathrm{~mL}\right.$ of $\mathrm{H}_{2} \mathrm{O}_{2}$ and $1 \mathrm{~mL}$ of $\mathrm{HNO}_{3}$ ). The $\mathrm{Zr}$ contents in the cell lysis solution were determined by ICP-MS.

In vitro cell viability assay. 4T1 cells were seeded into 96-well plates at the density of 6000 cells per well (100 $\mu$ L of RPMI 1640 medium). Then the cells were incubated with YNPs and ZrNPs for $24 \mathrm{~h}$ with various concentrations, respectively (YNPs in $0.67 \mu \mathrm{L}$ of dimethyl sulfoxide(DMSO) were added and the final concentrations in RPMI 1640 medium are $0,12.5,25,50,100,200,400 \mu \mathrm{g} \mathrm{mL}^{-1}$, respectively; ZrNPs in $0.67 \mu \mathrm{L}$ of DMSO were added and the final concentrations in RPMI 1640 medium are $0,12.5,25,50,100,200 \mu \mathrm{g} \mathrm{mL}^{-1}$, respectively). In the control group, $0.67 \mu \mathrm{L}$ of DMSO was added. The cell viability was calculated using a typical methyl thiazolyl tetrazolium (MTT) assay following the manufacture's protocol. To further evaluate the toxicity affects of ZrNPs on normal cells, L929 cells were seeded into 96-well plates at the density of 6000 cells per well $(100 \mu \mathrm{L}$ of DMEM medium). Then the cells were incubated with ZrNPs for $24 \mathrm{~h}$ with various concentrations (ZrNPs: 0, $\left.12.5,25,50,100,200 \mu \mathrm{g} \mathrm{mL}^{-1}\right)$. The cell viability was calculated using a typical MTT assay. 
Intracellular reactive oxygen species (ROS) detection. 4T1 cells were seeded into 6-well plates at the density of $2 \times 10^{5}$ cells per well ( $1 \mathrm{~mL}$ of RPMI 1640 medium) and then incubated with DMSO (3.33 $\mu \mathrm{L}$ ), YNPs in $3.33 \mu \mathrm{L}$ of DMSO (the final concentrations in RPMI 1640 medium is $100 \mu \mathrm{g} \mathrm{mL}$ ${ }^{1}$ ) and $\mathrm{ZrNPs}$ in $3.33 \mu \mathrm{L}$ of DMSO (the final concentrations in RPMI 1640 medium is $100 \mu \mathrm{g} \mathrm{mL} \mathrm{m}^{-1}$ ) for $4 \mathrm{~h}$, respectively. Next, the culture media were replaced by fresh culture media and $2^{\prime}, 7^{\prime}-$ dichlorofluorescin diacetate (DCFH-DA) was added to each well and the mixture was incubated for $30 \mathrm{~min}$ at $37^{\circ} \mathrm{C}$. Lastly, the fluorescence was detected by inverted fluorescence microscope (Nikon). For fluorescent quantitative analysis of 2',7'-dichlorofluorescein (DCF), the cells were further handled using trypsinization to obtain a single cell suspension and analyzed by flow cytometry (guava easyCyte $\left.{ }^{\mathrm{TM}}\right)$.

Flow-cytometry apoptosis assay. $4 \mathrm{~T} 1$ cells were seeded into 12 -well plates at the density of $1 \times 10^{5}$ cells per well (1 mL of RPMI 1640 medium) and then incubated with DMSO (3.33 $\mu \mathrm{L})$, YNPs in 3.33 $\mu \mathrm{L}$ of DMSO (the final concentrations in RPMI 1640 medium is $25 \mu \mathrm{g} \mathrm{mL}^{-1}$ ) and $\mathrm{ZrNPs}$ in $3.33 \mu \mathrm{L}$ of DMSO (the final concentrations in RPMI 1640 medium is $25 \mu \mathrm{g} \mathrm{mL}^{-1}$ ) for $24 \mathrm{~h}$, respectively. The single cell suspension was further obtained and stained with annexin-FITC and prodium iodide (PI) for flow cytometry (guava easyCyte ${ }^{\mathrm{TM}}$ ).

Bio-transmission electron microscopy (bio-TEM). To prove the obtained nanoparticles being internalized by $4 \mathrm{~T} 1$ cells, $4 \mathrm{~T} 1$ cells were seeded into culture plates at a density of $4 \times 10^{6}$ cells per dish (8 mL of RPMI 1640 medium) and treated with DMSO $(26.7 \mu \mathrm{L})$, YNPs in $26.7 \mu \mathrm{L}$ of DMSO (the final concentrations in RPMI 1640 medium is $100 \mu \mathrm{g} \mathrm{mL}-1$ ) and ZrNPs in $26.7 \mu \mathrm{L}$ of DMSO (the final concentrations in RPMI 1640 medium is $100 \mu \mathrm{g} \mathrm{mL}^{-1}$ ) for $10 \mathrm{~h}$, respectively. Subsequently, the cells were washed repeatedly with PBS and collected for bio-TEM imaging.

Cell morphology observation. 4T1 cells were seeded into 12 -well plates at the density of $1 \times 10^{5}$ cells per well (1 mL of RPMI 1640 medium) and then incubated with DMSO (3.33 $\mu \mathrm{L})$, YNPs in $3.33 \mu \mathrm{L}$ 
of DMSO (the final concentrations in RPMI 1640 medium is $100 \mu \mathrm{g} \mathrm{mL}^{-1}$ ) and ZrNPs in $3.33 \mu \mathrm{L}$ of DMSO (the final concentrations in RPMI 1640 medium is $100 \mu \mathrm{g} \mathrm{mL}^{-1}$ ) for $24 \mathrm{~h}$, respectively. The morphology of cells was further observed by inverted fluorescence microscope (Nikon). To further study the morphology change, 4T1 cells were seeded into 96 -well plates at the density of $6 \times 10^{3}$ cells per well $\left(0.1 \mathrm{~mL}\right.$ of RPMI 1640 medium) and then incubated with ZrNPs $\left(200 \mu \mathrm{g} \mathrm{mL}^{-1}\right)$. The morphology of cells was observed by automated microscope \& multi-mode plate reader (BioTek Cytation TM 5) with one photo per two minutes and a video was created finally.

Lactic dehydrogenase (LDH) assays. 4T1 cells were seeded into 96-well plates at the density of 6× $10^{3}$ cells per well (0.2 mL of RPMI 1640 medium) and then incubated with DMSO $(0.67 \mu \mathrm{L})$, YNPs in $0.67 \mu \mathrm{L}$ of DMSO (the final concentrations in RPMI 1640 medium is $100 \mu \mathrm{g} \mathrm{mL}^{-1}$ ) and $\mathrm{ZrNPs}$ (the final concentrations in RPMI 1640 medium is $100 \mu \mathrm{g} \mathrm{mL}^{-1}$ ) for $24 \mathrm{~h}$, respectively. The release of LDH was detected by the LDH cytotoxicity assay kit (Beyotime, C0016) according to the manufacturer's protocols.

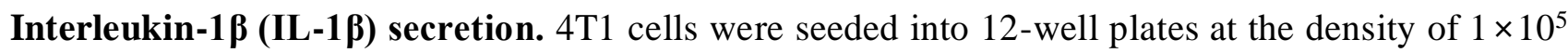
cells per well (1 mL of RPMI 1640 medium) and then incubated with DMSO (3.33 $\mu \mathrm{L})$, YNPs in 3.33 $\mu \mathrm{L}$ of DMSO (the final concentrations in RPMI 1640 medium is $50 \mu \mathrm{g} \mathrm{mL}^{-1}$ ) and ZrNPs in $3.33 \mu \mathrm{L}$ of DMSO (the final concentrations in RPMI 1640 medium is $50 \mu \mathrm{g} \mathrm{mL}^{-1}$ ) for $24 \mathrm{~h}$, respectively. The release of IL- $1 \beta$ was detected by the IL-1 $\beta$ enzyme-linked immunosorbent assay (ELISA) kit (Tianjin Anoric Bio-technology) according to the manufacturer's protocols.

Intracellular $\mathrm{K}^{+}$ions detection. Intracellular $\mathrm{K}^{+}$ions detection was examined by a $\mathrm{K}^{+}$ions probe enhanced potassium green-2 AM (EPG-2 AM, Maokangbio). 4T1 cells were seeded into 6-well plates at the density of $1.5 \times 10^{5}$ cells per well ( $1 \mathrm{~mL}$ of RPMI 1640 medium). Firstly, $5 \mu \mathrm{L}$ of DMSO mixed solution of EPG-2 AM (1 mM) and F-127 (10\%) was added and then the 6-well plate was incubated for $30 \mathrm{~min}$ at $37^{\circ} \mathrm{C}$. After that, $4 \mathrm{~T} 1$ cells were incubated with $\mathrm{KCl}\left(0.44 \mu \mathrm{mol} \mathrm{mL} \mathrm{m}^{-1}, 32.8 \mu \mathrm{g} \mathrm{mL} \mathrm{m}^{-1}\right)$ 
and ZrNPs $\left(0.147 \mu \mathrm{mol} \mathrm{mL}^{-1}\right)$ for $4 \mathrm{~h}$, respectively. Next, the culture media were replaced and washed by fresh culture media. Finally, the cells were stained with Hoechst 33342 (Hoechst, $2 \mu \mathrm{g} \mathrm{mL}^{-1}$ ) for 10 min and then observed under inverted fluorescence microscope (Nikon).

Cleaved caspase-1 (c-Cas-1) expression. Briefly, 4T1 cells were seeded into 6-well culture plates at a density of $1 \times 10^{5}$ cells per well ( $1 \mathrm{~mL}$ of RPMI 1640 medium) and then incubated with DMSO $(3.33 \mu \mathrm{L}$ ), YNPs in $3.33 \mu \mathrm{L}$ of DMSO (the final concentrations in RPMI 1640 medium is $100 \mu \mathrm{g} \mathrm{mL}$ ${ }^{1}$ ) and ZrNPs in $3.33 \mu \mathrm{L}$ of DMSO (the final concentrations in RPMI 1640 medium is $100 \mu \mathrm{g} \mathrm{mL}^{-1}$ ), respectively. After $24 \mathrm{~h}$ of incubation in the dark, the cells were washed repeatedly with PBS and then treated with $4 \%$ paraformaldehyde for $20 \mathrm{~min}$. Then $0.1 \%$ triton and goat serum were added for 20 min and $10 \mathrm{~min}$, respectively. After that, the cells were incubated with rabbit anti-cleaved caspase-1 antibody (Absin, abs143596, 1:200) for $10 \mathrm{~h}$ at $4{ }^{\circ} \mathrm{C}$. Subsequently, the cells were further incubated with FITC-conjugated secondary antibody (Goat anti-rabbit IgG antibody, Absin, 1:100) for 40 min at $37^{\circ} \mathrm{C}$. Finally the cells were stained with Hoechst for $10 \mathrm{~min}$ and then observed under laser scanning confocal microscopy (LSCM).

Western blot. For western blots of c-Cas-1 and cleaved gasdermin D (c-GSDMD, Cell Signaling Technology, Asp276) expressions, 4T1 cells were seeded into culture plates at a density of $5 \times 10^{6}$ cells per dish (8 mL of RPMI 1640 medium) and treated with DMSO $(26.7 \mu \mathrm{L})$, YNPs in $26.7 \mu \mathrm{L}$ of DMSO (the final concentrations in RPMI 1640 medium is $100 \mu \mathrm{g} \mathrm{mL}^{-1}$ ) and ZrNPs in $26.7 \mu \mathrm{L}$ of DMSO (the final concentrations in RPMI 1640 medium is $100 \mu \mathrm{g} \mathrm{mL} \mathrm{m}^{-1}$ ) for $10 \mathrm{~h}$, respectively. Subsequently, the cells were washed repeatedly with PBS and collected for a standard western blot process.

Gene sequencing. $4 \mathrm{~T} 1$ cells were seeded into culture plates at a density of $5 \times 10^{6}$ cells per dish ( 8 $\mathrm{mL}$ of RPMI 1640 medium) and treated with DMSO $(26.7 \mu \mathrm{L})$, YNPs in $26.7 \mu \mathrm{L}$ of DMSO (the final concentrations in RPMI 1640 medium is $100 \mu \mathrm{g} \mathrm{mL}-1$ ) and ZrNPs in $26.7 \mu \mathrm{L}$ of DMSO (the final 
concentrations in RPMI 1640 medium is $100 \mu \mathrm{g} \mathrm{mL}-1$ ) for $10 \mathrm{~h}$, respectively. Subsequently, the cells were washed repeatedly with PBS and collected for gene sequencing (The Beijing Genomics Institute). In vivo UCL imaging. For in vivo UCL imaging, $4 \mathrm{~T} 1$ tumor-bearing $\mathrm{BALB} / \mathrm{c}$ mice with intratumor injection of YNPs or ZrNPs were imaged on an in vivo Maestro whole-body imaging system equipped with an external $980 \mathrm{~nm}$ laser as the excitation source at various time periods (5 min, 30 min and 60 $\min )$.

Dendritic cells (DCs) and $T$ cells measurements in spleen and tumor-draining lymph node (TDLN). 4T1 tumor-bearing BALB/c mice were randomly allocated into 3 groups $(n=4)$, which were injected with three intratumor injections of (1) DMSO $(26.7 \mu \mathrm{L})$; (2) YNPs in $26.7 \mu \mathrm{L}$ of DMSO (800 $\mu \mathrm{g} /$ mouse); (3) ZrNPs in $26.7 \mu \mathrm{L}$ of DMSO (800 $\mu \mathrm{g} /$ mouse) on day 8, 10, 12 (the day of the tumor inoculation is marked as day 0), respectively. The mice were sacrificed on day 22 and the single cell suspensions of spleen and TDLN were obtained according to the standard protocol. Next, cell counting was carried out and $0.5 \times 10^{7}$ cells per sample were obtained. Then $7.4 \mu \mathrm{L}$ of mixed solution of fluorochrome-conjugated anti-mouse antibodies (containing $60 \mu \mathrm{L}$ of FITC anti-mouse CD3 $\varepsilon, 160 \mu \mathrm{L}$ of Brilliant Violet $650^{\mathrm{TM}}$ anti-mouse CD4, $160 \mu \mathrm{L}$ of APC/Cyanine7 anti-mouse CD8a, $80 \mu \mathrm{L}$ of Brilliant Violet $605^{\mathrm{TM}}$ anti-mouse/human $\mathrm{CD} 44,40 \mu \mathrm{L}$ of $\mathrm{PE}$ anti-mouse CD62L, $40 \mu \mathrm{L}$ of PE/Cyanine7 anti-mouse CD11c, $160 \mu \mathrm{L}$ of Brilliant Violet $421^{\mathrm{TM}}$ anti-mouse CD80, $40 \mu \mathrm{L}$ of APC anti-mouse CD86; all antibodies were purchased from BioLegend) were added into cell samples. The obtained cells and antibodies solution was stored in $4{ }^{\circ} \mathrm{C}$ for $1 \mathrm{~h}$ in the dark. After that, the cells were washed with PBS twice and then dispersed in $0.5 \mathrm{~mL}$ of PBS for surface marker detection directly by flow cytometry (BD FACSCelesta ${ }^{\mathrm{TM}}$ ). The cell sorting process for analysis of immune cells was shown in Figure S26.

In vivo anti-tumor effect. Female Balb/c mice (17-21 g) were purchased from the Center for Experimental Animals, Jilin University (Changchun, China). $100 \mu \mathrm{L}$ of $4 \mathrm{~T} 1$ cells in PBS $\left(1 \times 10^{7}\right.$ 
cells per $\mathrm{mL})$ were inoculated into $\mathrm{BALB} / \mathrm{c}$ mice $\left(1 \times 10^{6}\right.$ cells per mouse $)$ at the left back. When tumor sizes are about 50-60 $\mathrm{mm}^{3}$ (8 days), 4T1 tumor-bearing BALB/c mice were randomly allocated into 3 groups $(n=6)$, which were injected with three intratumor injections of (1) DMSO $(26.7 \mu \mathrm{L}) ;(2)$ YNPs in $26.7 \mu \mathrm{L}$ of DMSO (800 $\mu \mathrm{g} / \mathrm{mouse})$; (3) ZrNPs in $26.7 \mu \mathrm{L}$ of DMSO (800 $\mu \mathrm{g} / \mathrm{mouse}$ ) on day $0,2,4$, respectively. The tumor sizes were measured every 2 days and body weights were recorded at the same time. The tumor volume was estimated by $\mathrm{L} \times \mathrm{W}^{2} / 2$, where $\mathrm{L}$ and $\mathrm{W}$ refer to the length and width of the tumor, respectively. On day 14 , all of mice were sacrificed and the tumors were collected for staining.

In vivo antimetastatic studies. $100 \mu \mathrm{L}$ of $4 \mathrm{~T} 1$ cells in PBS $\left(1 \times 10^{7}\right.$ cells per $\left.\mathrm{mL}\right)$ were inoculated into BALB/c mice $\left(1 \times 10^{6}\right.$ cells per mouse $)$ at the left back. When tumor sizes are about $50-60 \mathrm{~mm}^{3}$ (8 days), 4T1 tumor-bearing BALB/c mice were randomly allocated into 3 groups $(n=3)$, which were injected with three intratumor injections of (1) DMSO $(26.7 \mu \mathrm{L})$; (2) YNPs in $26.7 \mu \mathrm{L}$ of DMSO (800 $\mu \mathrm{g} /$ mouse); (3) ZrNPs in $26.7 \mu \mathrm{L}$ of DMSO (800 $\mu \mathrm{g} /$ mouse) on day $0,2,4$, respectively. On day 22, all the mice were sacrificed. Major organs including heart, liver, spleen, lung and kidney were surgical removed and collected for haematoxylin and eosin (H\&E) analyses.

Statistical Analysis. Analysis of variance (ANOVA) was used to assess statistical significance. $* \mathrm{p}<0.05, * * \mathrm{p}<0.01, * * * \mathrm{p}<0.001$. 

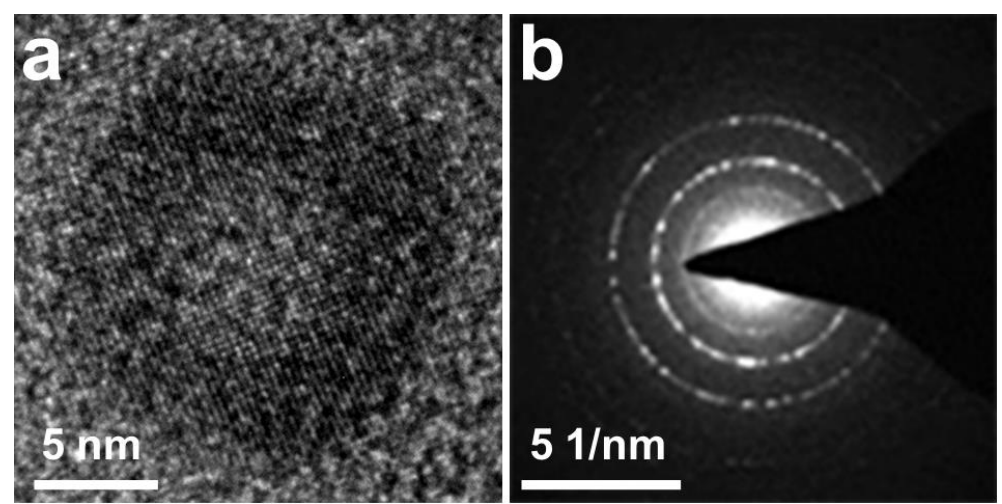

Figure S1. (a) The high-resolution transmission electron microscopy (HRTEM) image of ZrNPs. (b) Selected area electron diffraction (SAED) pattern of ZrNPs.

a

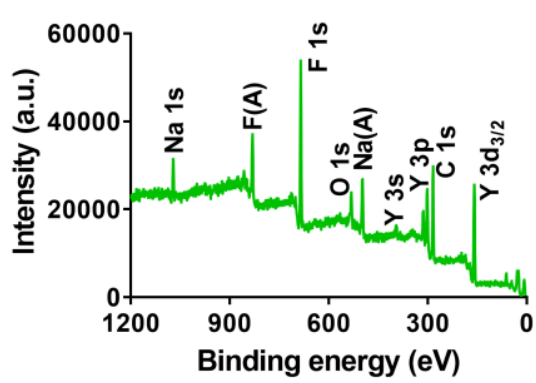

C

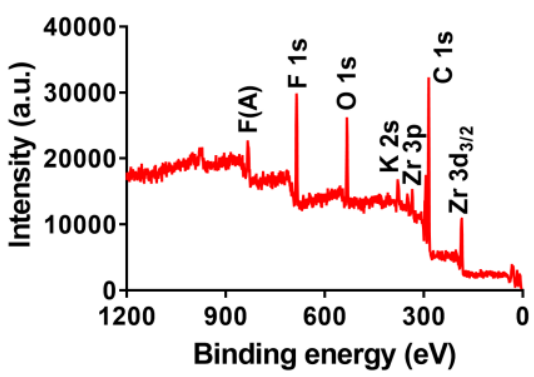

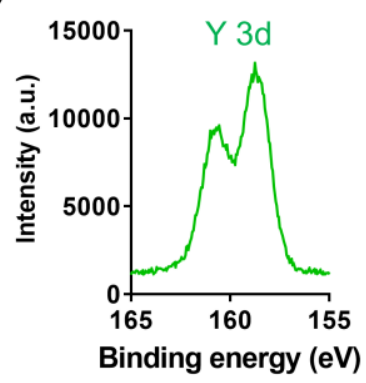

d

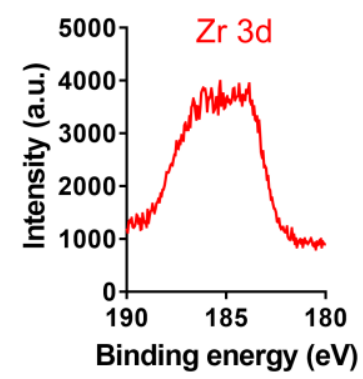

Figure S2. X-ray photoelectron spectroscopy (XPS) spectra of (a) YNPs and (c) ZrNPs. XPS highresolution scans of (b) Y 3d and (d) Zr 3d.

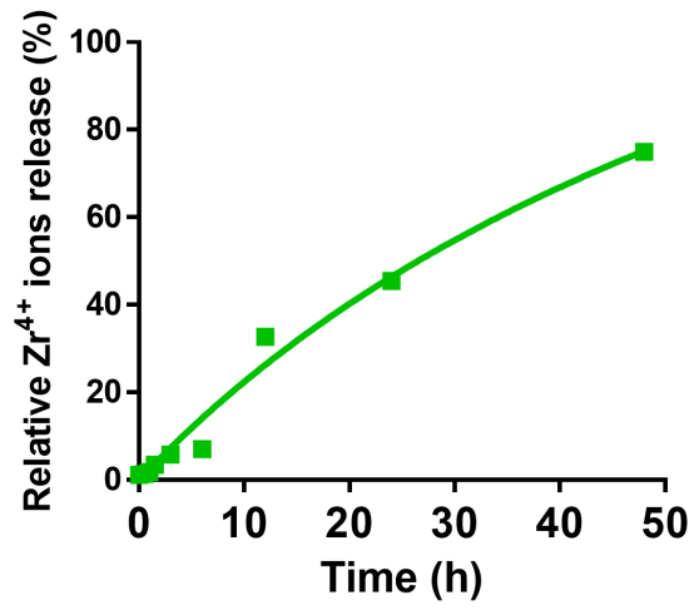

Figure S3. The relative $\mathrm{Zr}^{4+}$ ions release profile in cyclohexane-deionized water system. 


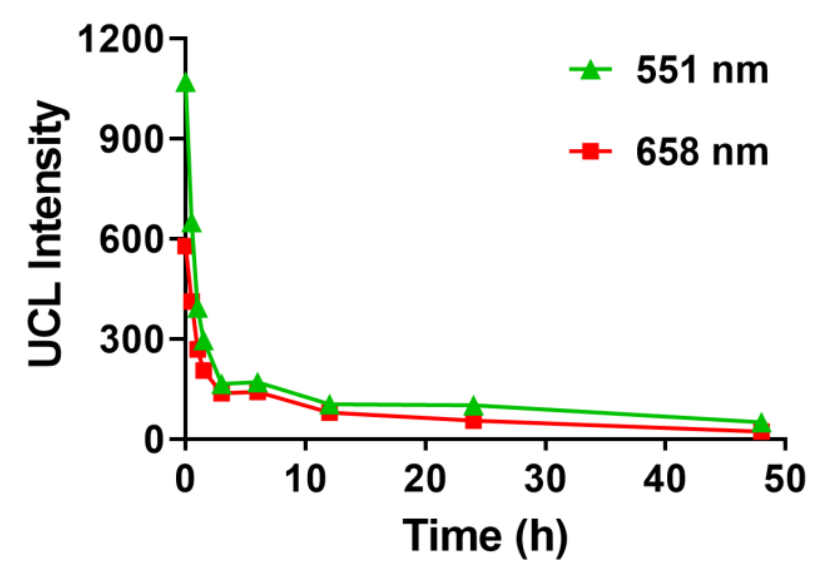

Figure S4. The UCL intensity changes of different emission peaks (551 nm and $658 \mathrm{~nm}$ ) of ZrNPs treated by water with different time $(0,0.5,1,1.5,3,6,12,24$, and $48 \mathrm{~h})$.

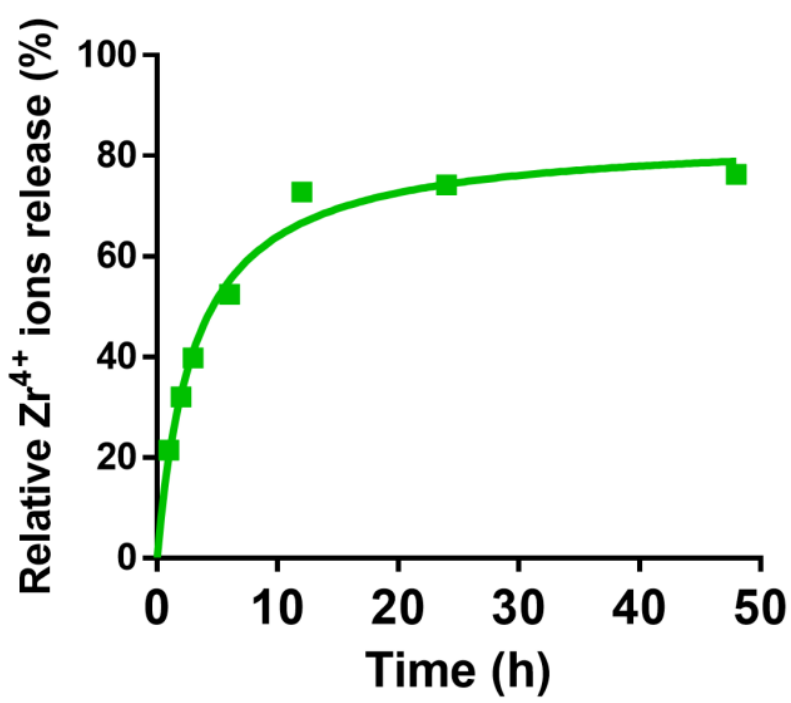

Figure S5. The relative $\mathrm{Zr}^{4+}$ ions release profile in DMSO-Roswell Park Memorial Institute (RPMI) 1640 medium system.
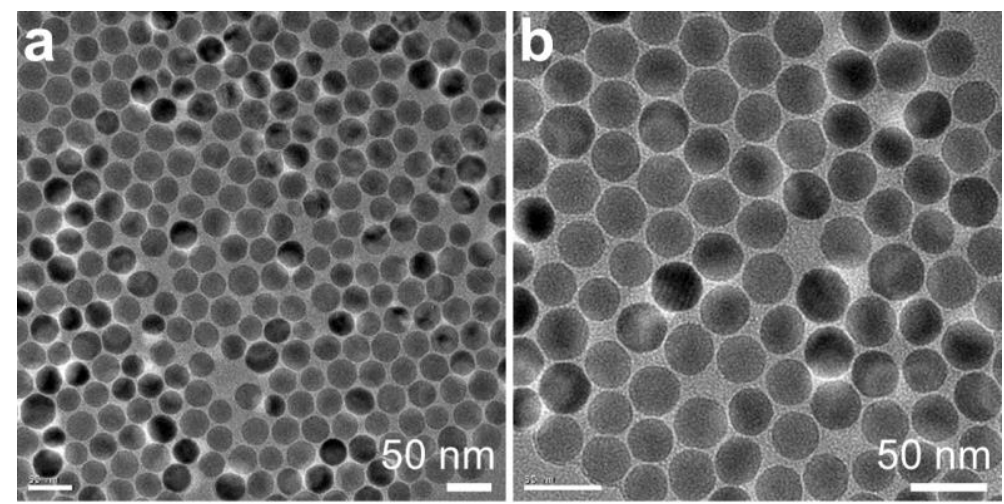

Figure S6. (a) and (b) TEM images of YNPs. 


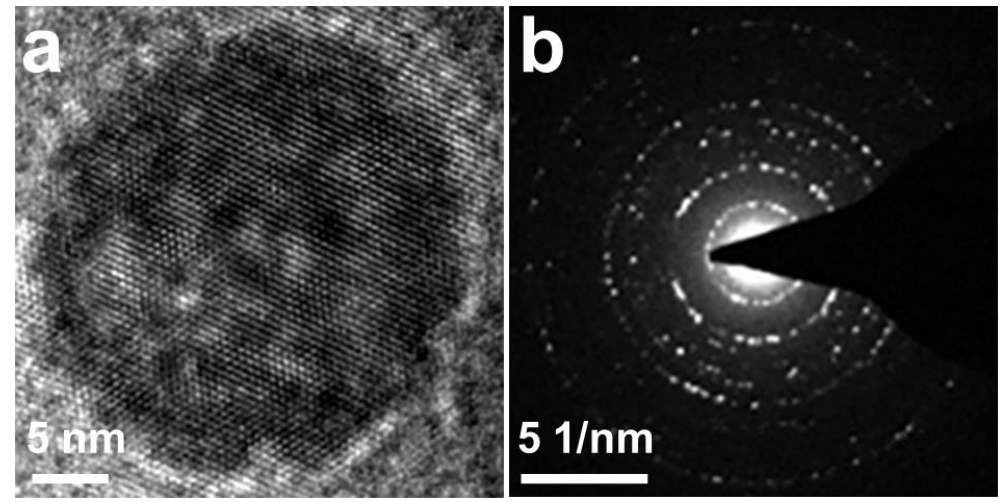

Figure S7. (a) HRTEM image of YNPs. (b) SAED pattern of YNPs.
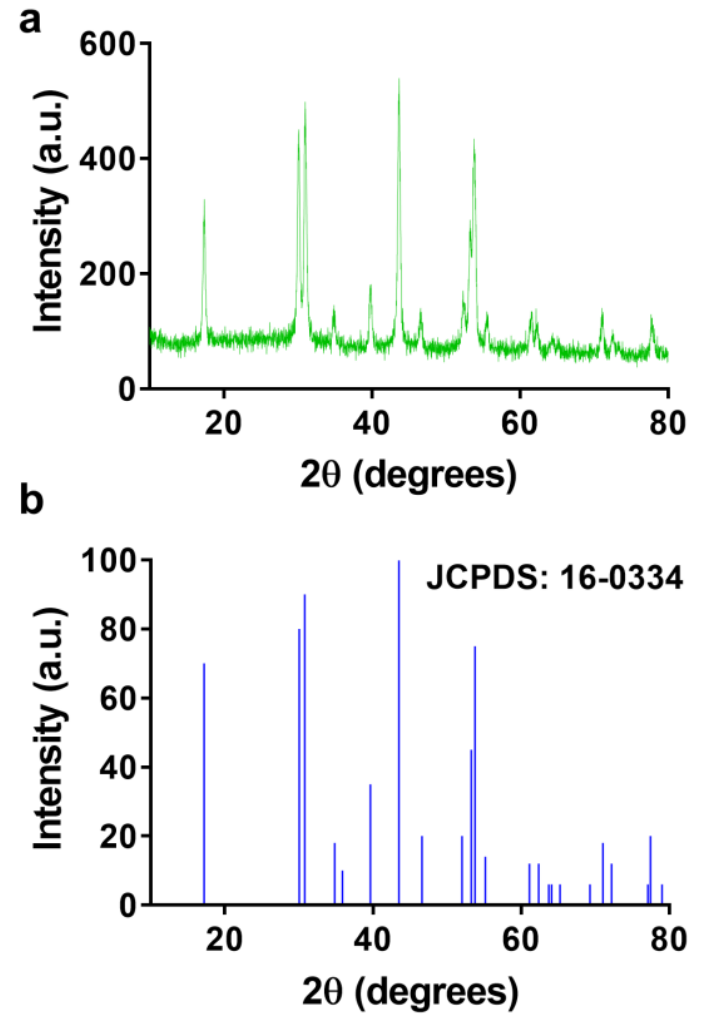

Figure S8. (a) XRD pattern of YNPs, which could be well indexed to (b) $\mathrm{NaYF}_{4}$ (JCPDS 16-0334). ${ }^{[1]}$ 


\section{Cyclohexane}

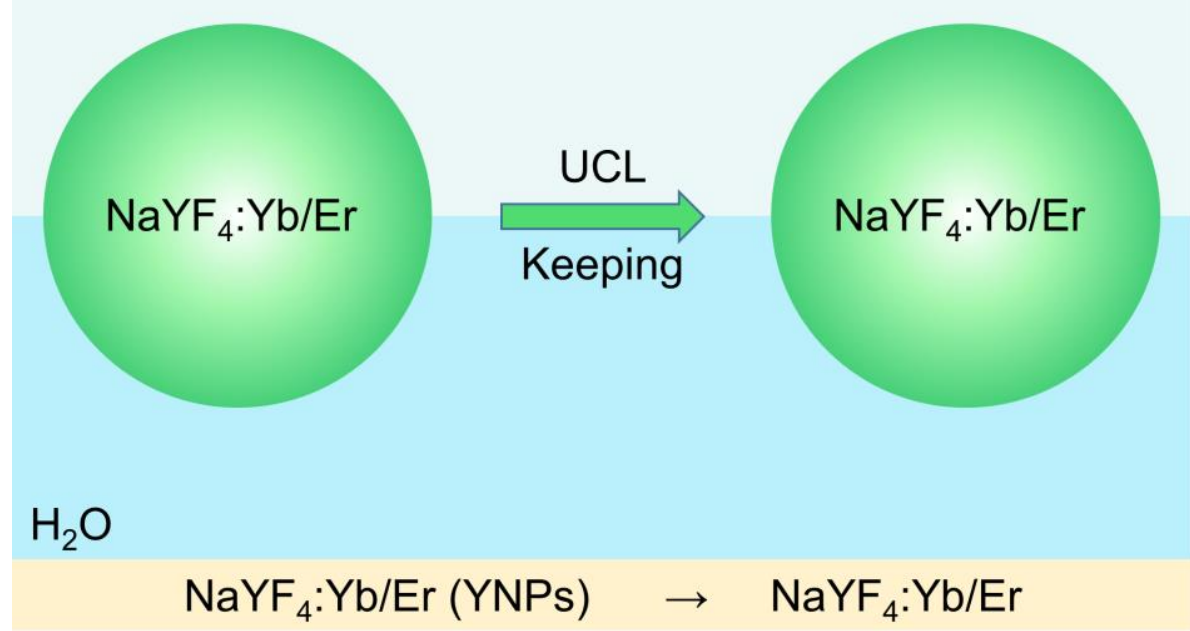

Figure S9. Schematic diagram of YNPs at the cyclohexane/water interface.

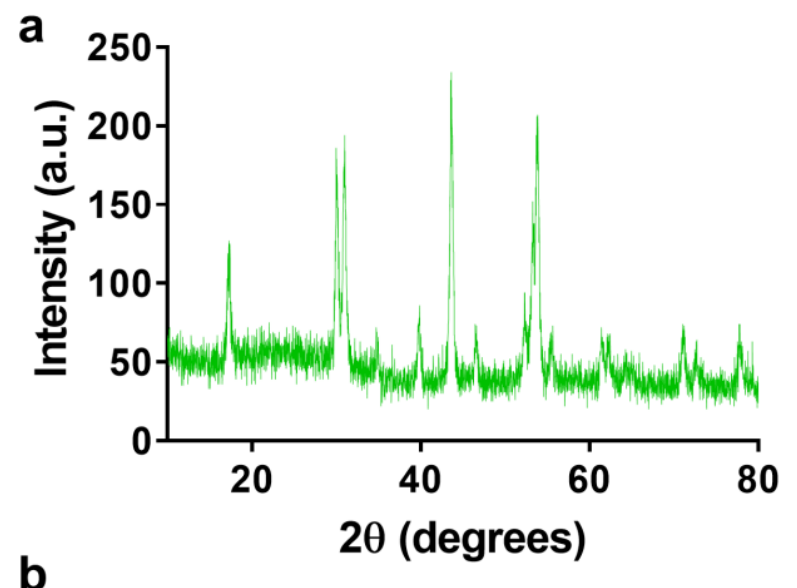

b

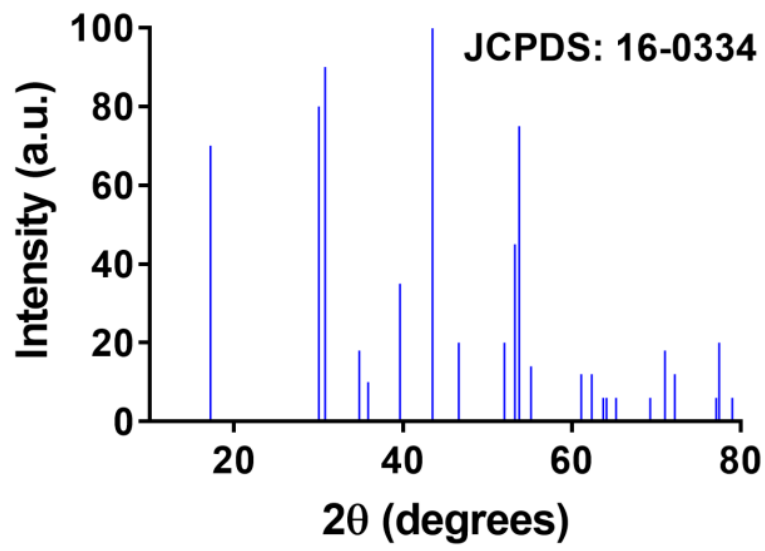

Figure S10. (a) XRD pattern of YNPs after treatments by water, which could be well indexed to (b) $\mathrm{NaYF}_{4}$ (JCPDS 16-0334), suggesting YNPs are chemically stable. 

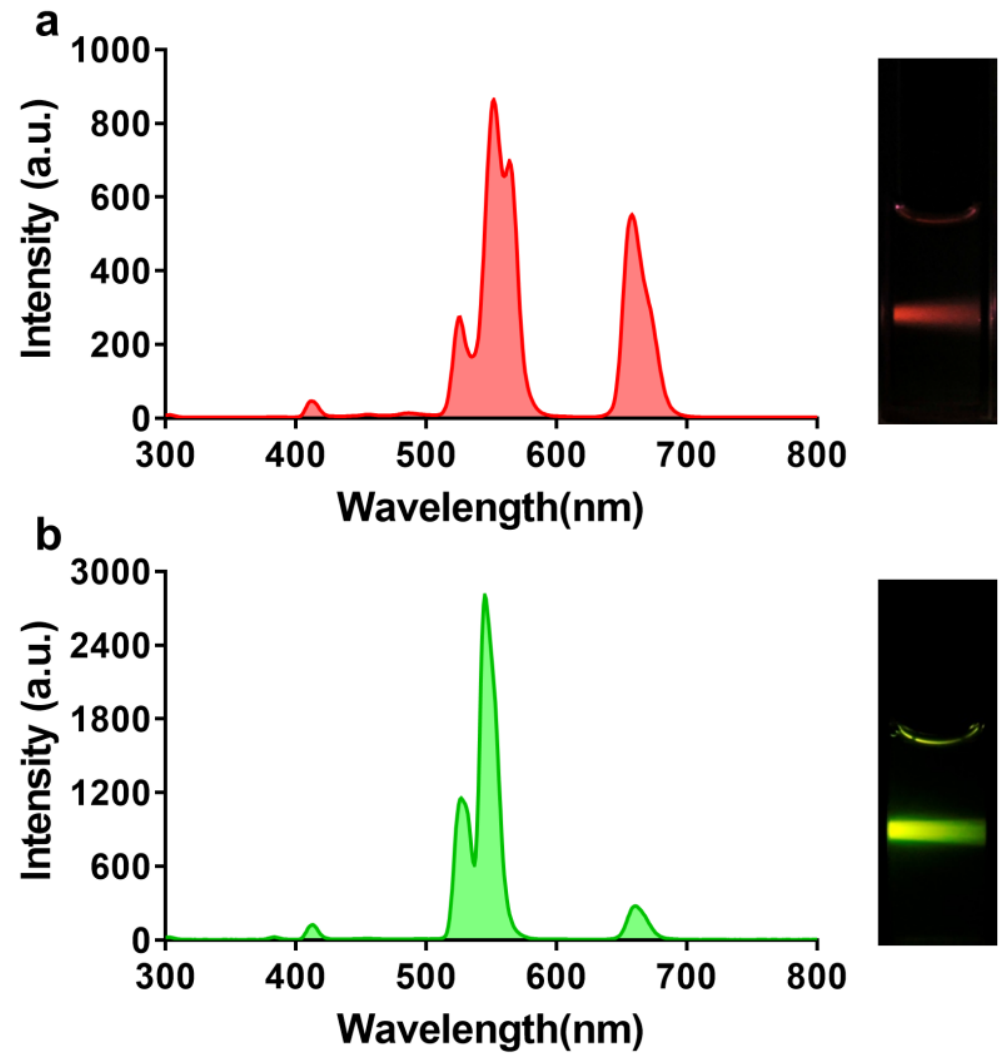

Figure S11. The upconversion fluorescence spectra of (a) ZrNPs and (b) YNPs under the irradiation of $980 \mathrm{~nm}$ laser.

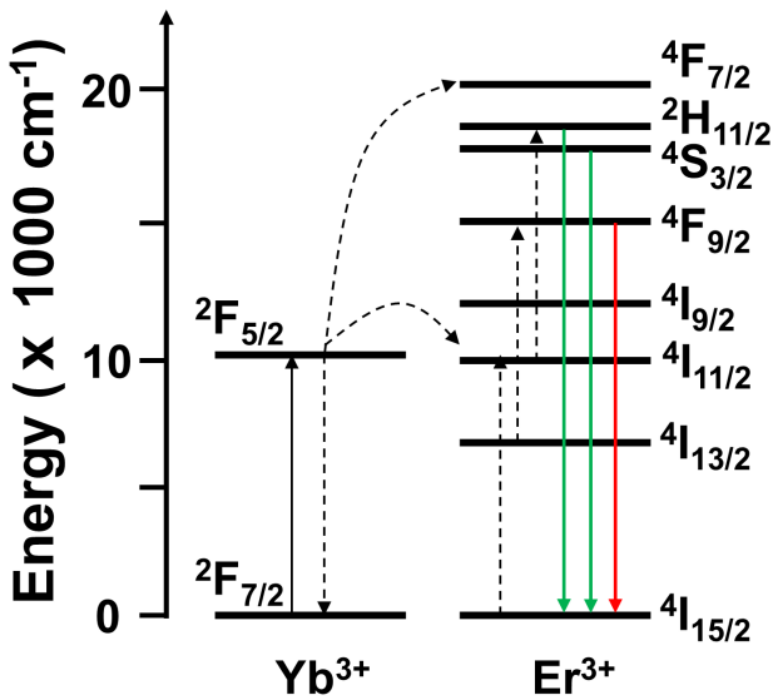

Figure S12. The proposed energy transfer mechanism under $980 \mathrm{~nm}$ NIR laser irradiation in ZrNPs and YNPs. ${ }^{[2]}$ 


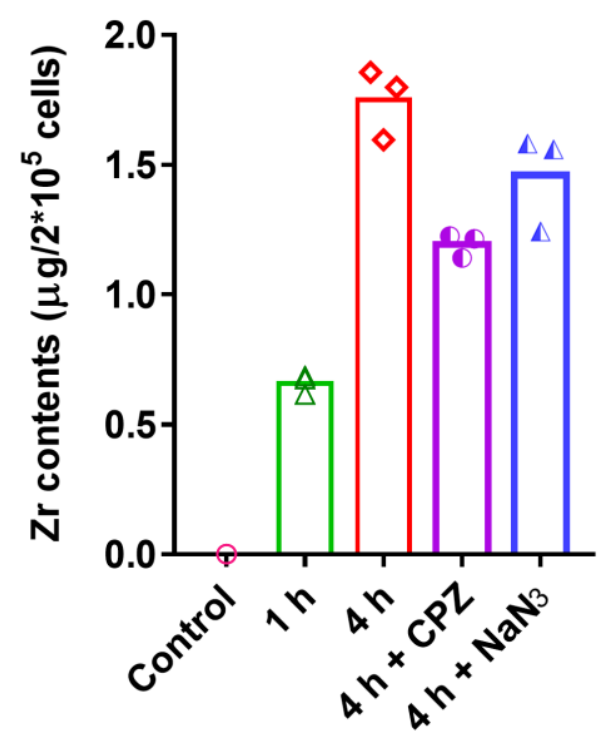

Figure S13. The mass of $\mathrm{Zr}$ internalized in $4 \mathrm{~T} 1$ cells after incubation with (1) control, (2) $\mathrm{ZrNPs}+1 \mathrm{~h}$, (3) ZrNPs $+4 \mathrm{~h}$, (4) endocytosis inhibitor chlorpromazine (CPZ) $+\mathrm{ZrNPs}+4 \mathrm{~h}$, and (5) energydepleting agent $\mathrm{NaN}_{3}+\mathrm{ZrNPs}+4 \mathrm{~h}$. With the increase in cellular uptake time, the $\mathrm{Zr}$ contents raised. In addition, the endocytosis inhibitor $\mathrm{CPZ}$ and energy-depleting agent $\mathrm{NaN}_{3}$ can inhibit the endocytosis of ZrNPs, indicating that hydrophobic ZrNPs enter 4T1 cells by endocytosis with an energy-dependent process.

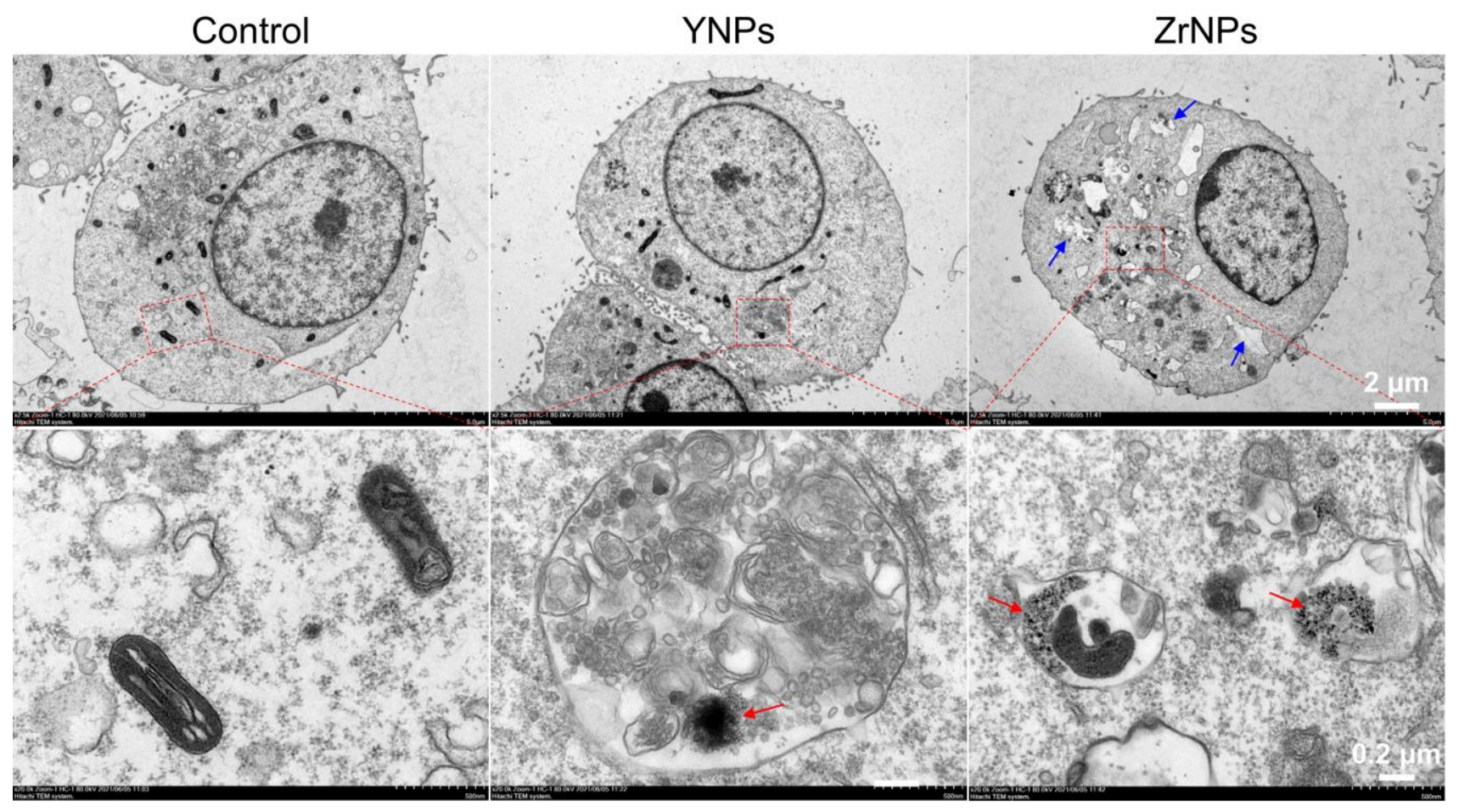

Figure S14. The bio-TEM images of 4T1 cells treated with control, YNPs and ZrNPs. After incubation with 4T1 cells, a large number of YNPs and ZrNPs were found in endosomes (red arrow) respectively, suggesting an efficient vesicular-mediated cellular uptake. What's more, compared with control and YNPs-treated 4T1 cells, ZrNPs caused an obvious mitochondrial destruction with noticeable swelling and cavitation of mitochondria (blue arrow), which may be attributed to sudden overdoses of ionsinduced a surge of intracellular osmolarity and reactive oxygen species (ROS) rise. 


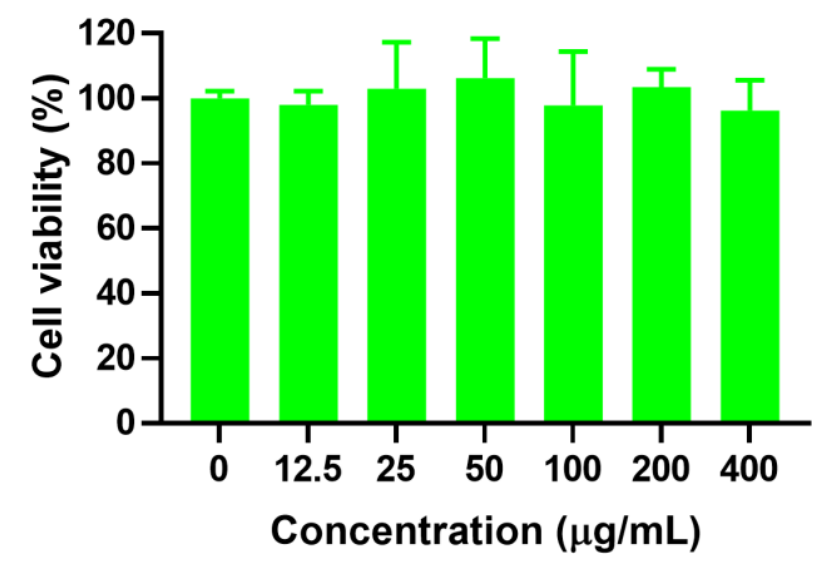

Figure S15. Relative cell viability of $4 \mathrm{~T} 1$ cells treated by YNPs with different concentrations $(0,12.5$, $25,50,100,200$, and $400 \mu \mathrm{g} / \mathrm{mL})$.

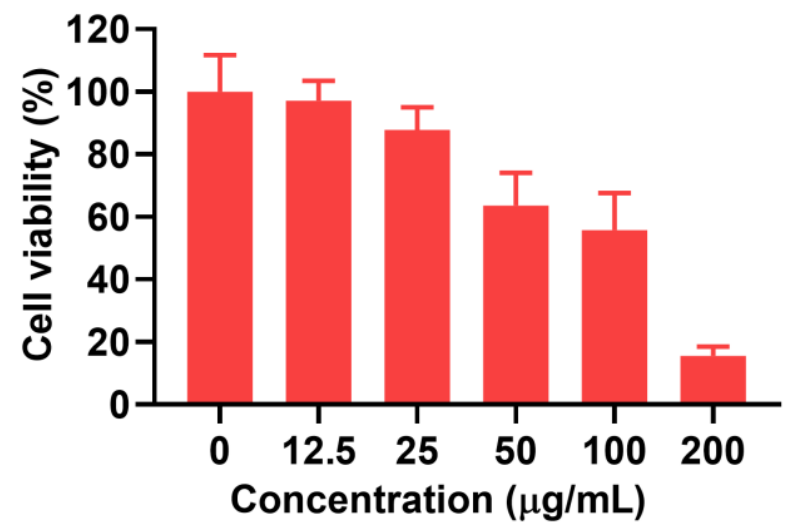

Figure S16. Relative cell viability of L929 cells treated by ZrNPs with different concentrations ( 0 , $12.5,25,50,100$ and $200 \mu \mathrm{g} / \mathrm{mL}$ ). The $50 \%$ inhibitory concentrations (IC50) of ZrNPs on L929 cells is $84 \mu \mathrm{g} / \mathrm{mL}$.

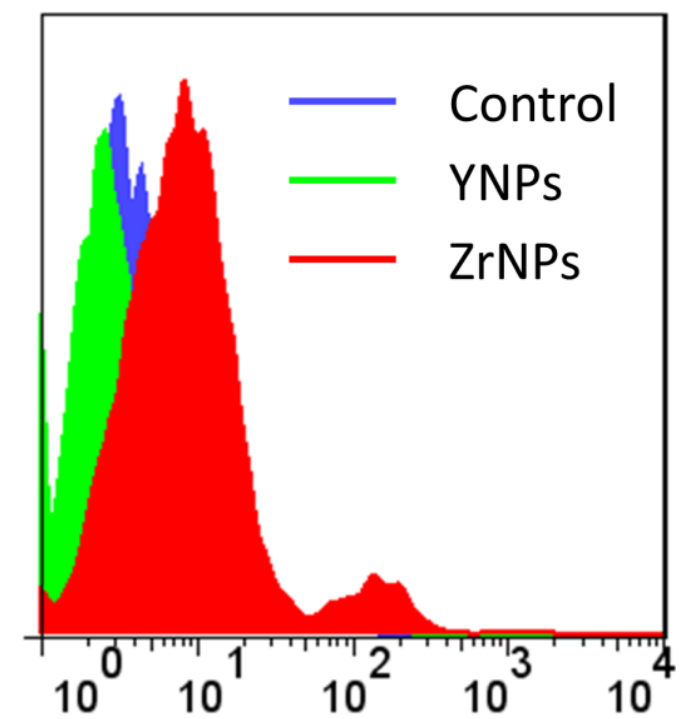

Figure S17. A quantitative analysis by flow cytometry about DCF. 


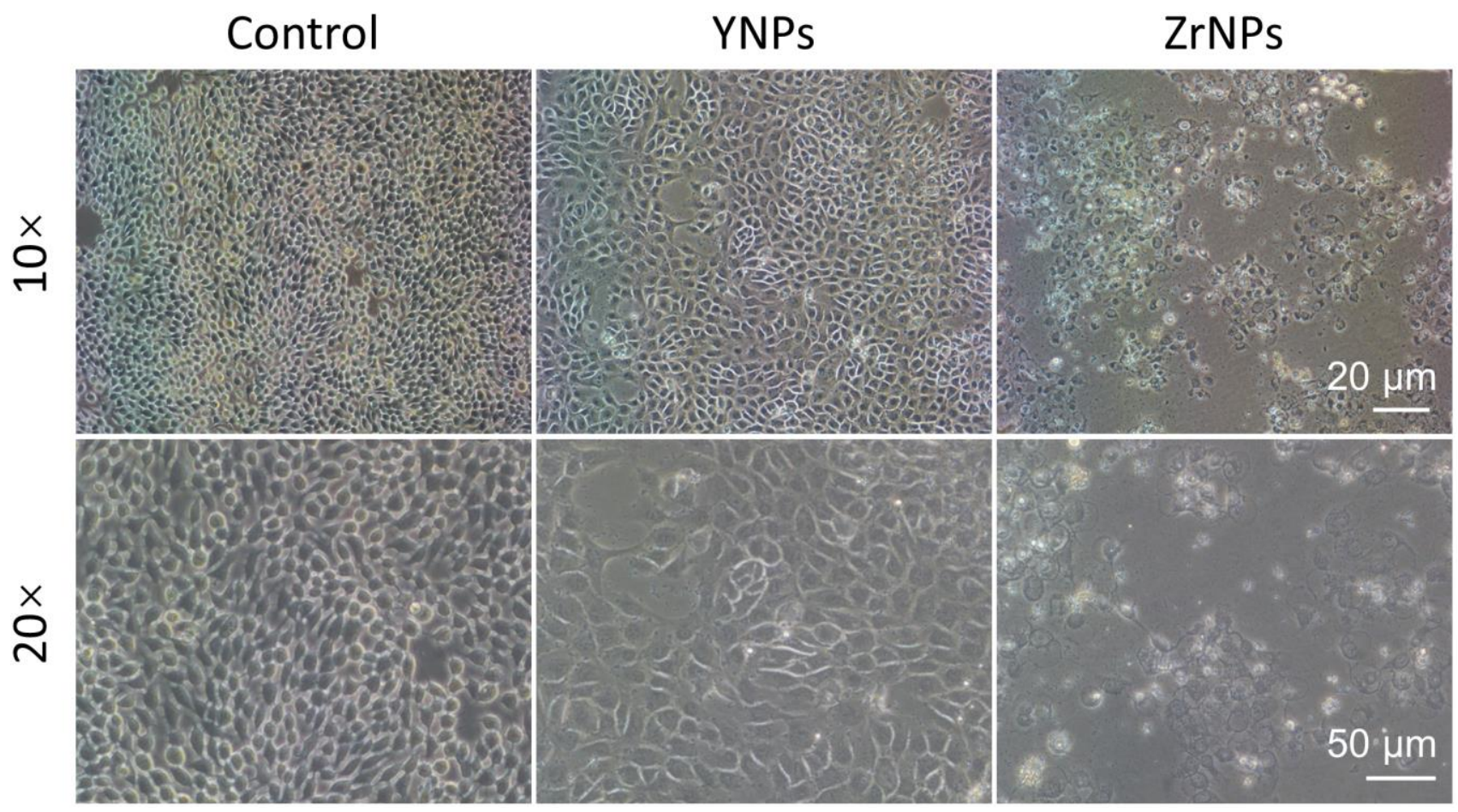

Figure S18. Cell morphology images with different treatments. Cell swelling with big bubbles can be observed in ZrNPs-treated group.

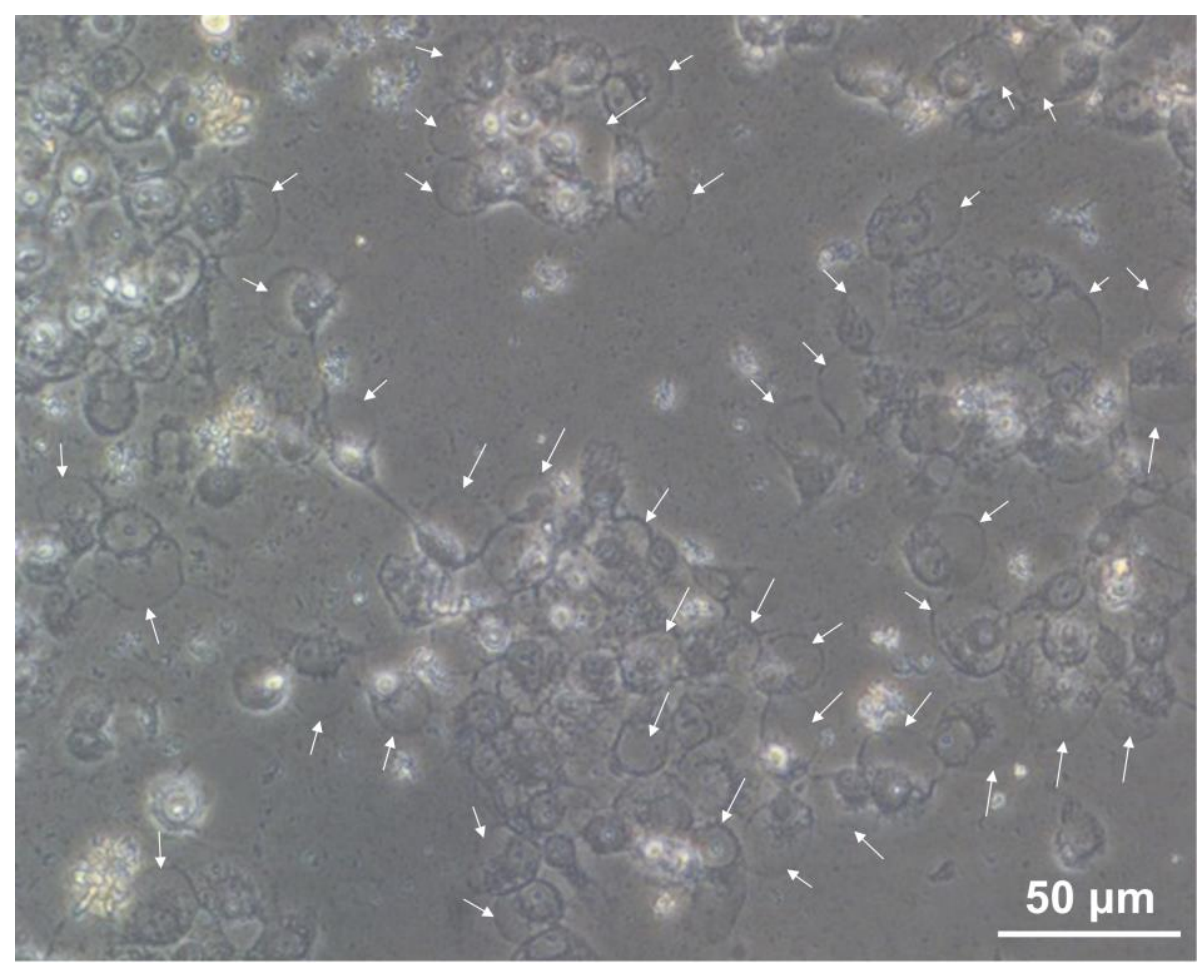

Figure S19. 4T1 cells morphology image treated with ZrNPs. Cell swelling with big bubbles can be observed (white arrow) in ZrNPs-treated group, which is a typical feature of pyroptosis. 


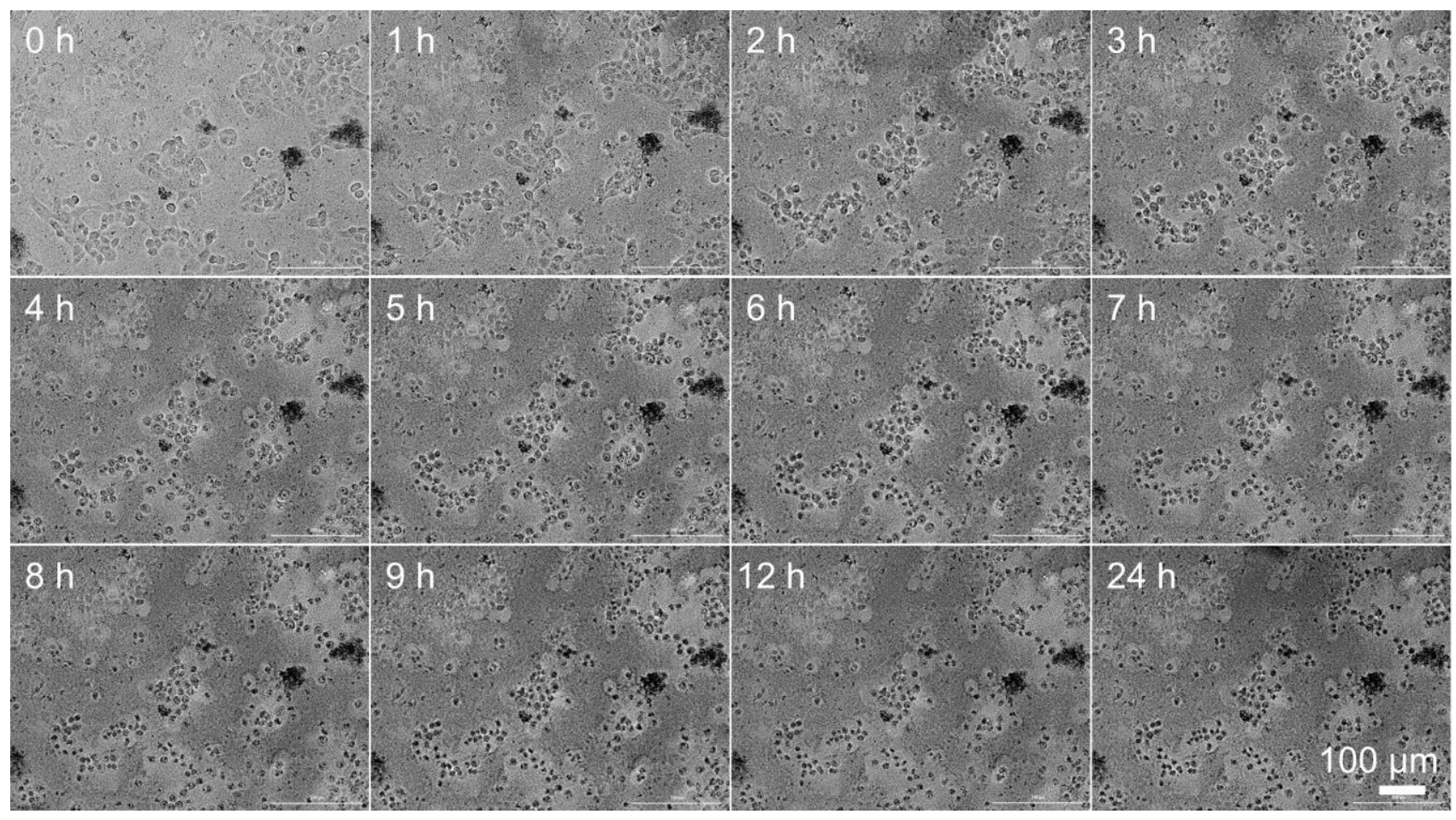

Figure S20. Real-time 4T1 cells morphology images treated with ZrNPs observed by automated microscope \& multi-mode plate reader (BioTek Cytation TM 5).

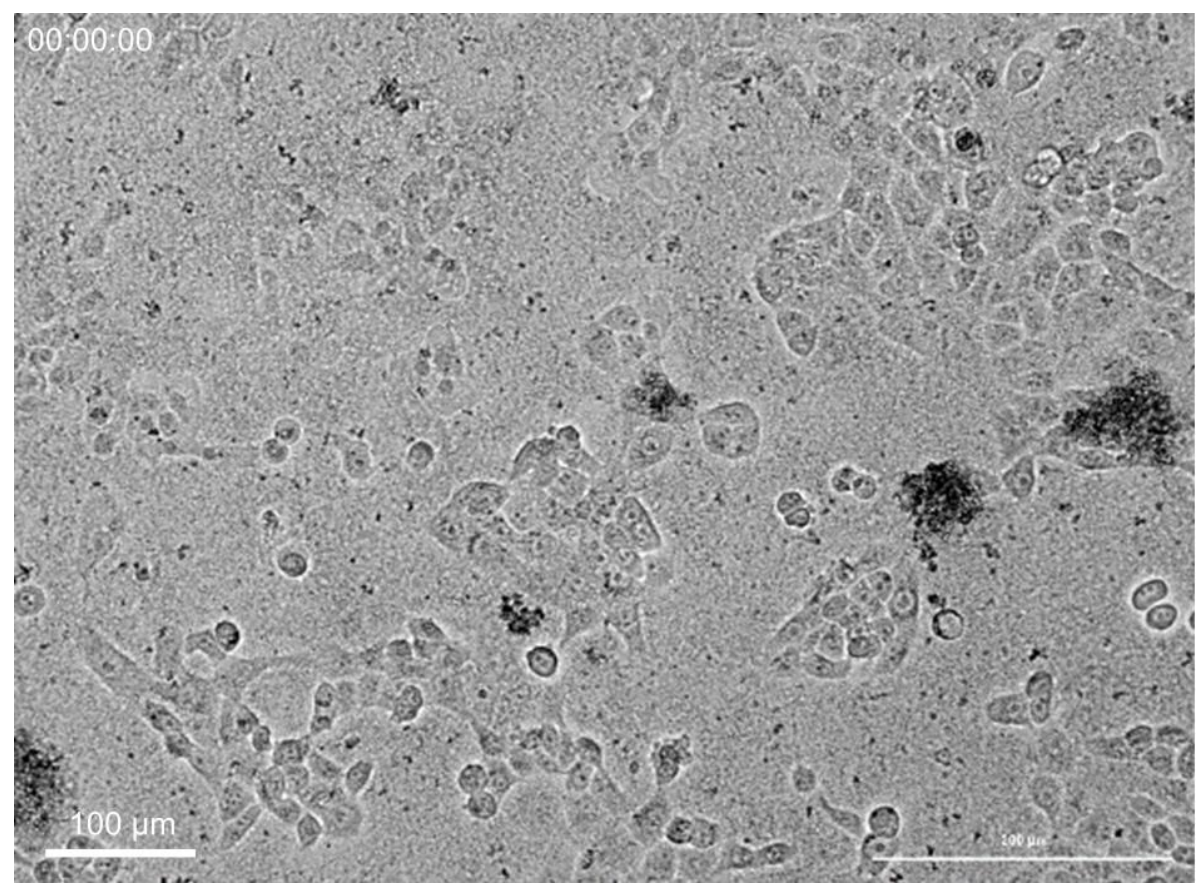

Figure S21. Real-time 4T1 cells morphology image treated with ZrNPs (t: 00:00:00). 


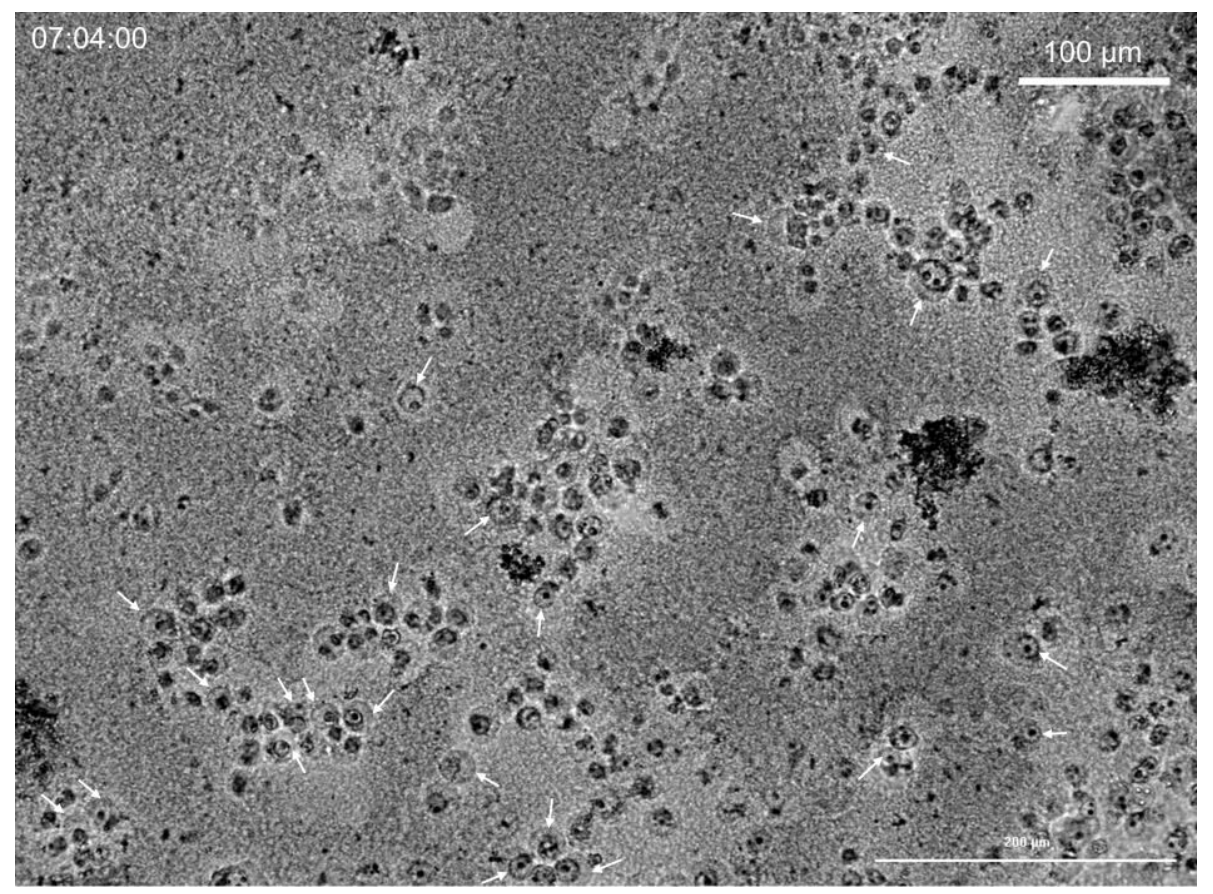

Figure S22. Real-time 4T1 cells morphology image treated with ZrNPs (t: 07:04:00). Cell swelling with big bubbles can be observed (white arrow).

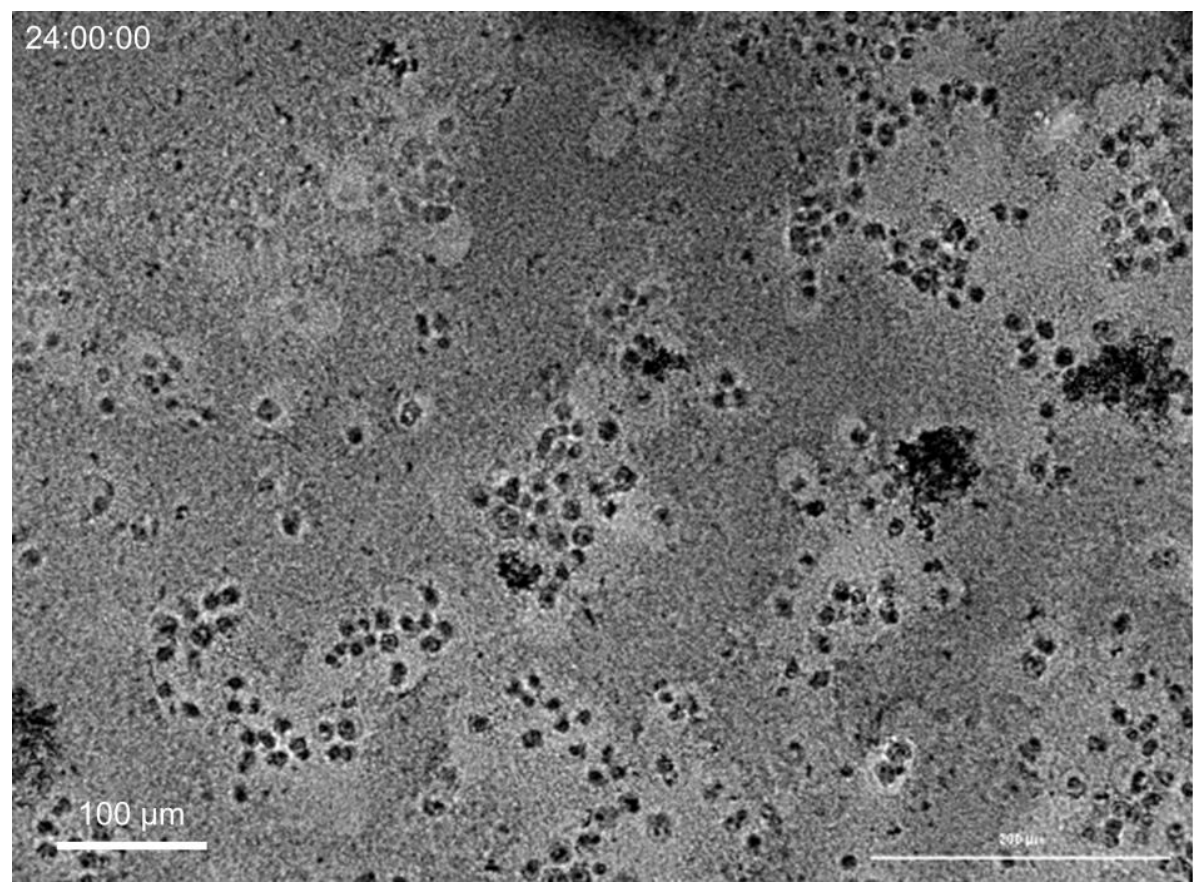

Figure S23. Real-time 4T1 cells morphology image treated with ZrNPs (t: 24:00:00). Obvious cell death can be observed. 

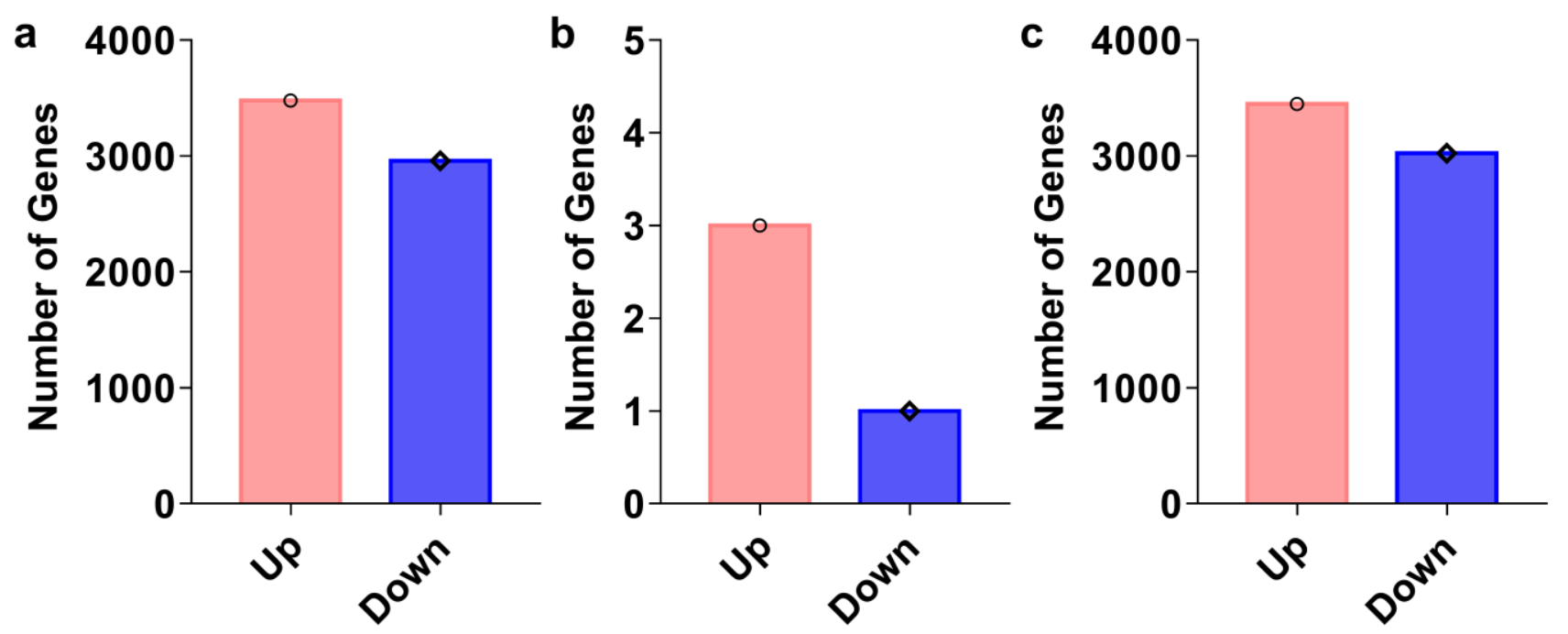

Figure S24. The number of differentially expressed genes in (1) Control and ZrNPs groups, (2) Control and YNPs groups, (3) YNPs and ZrNPs groups.

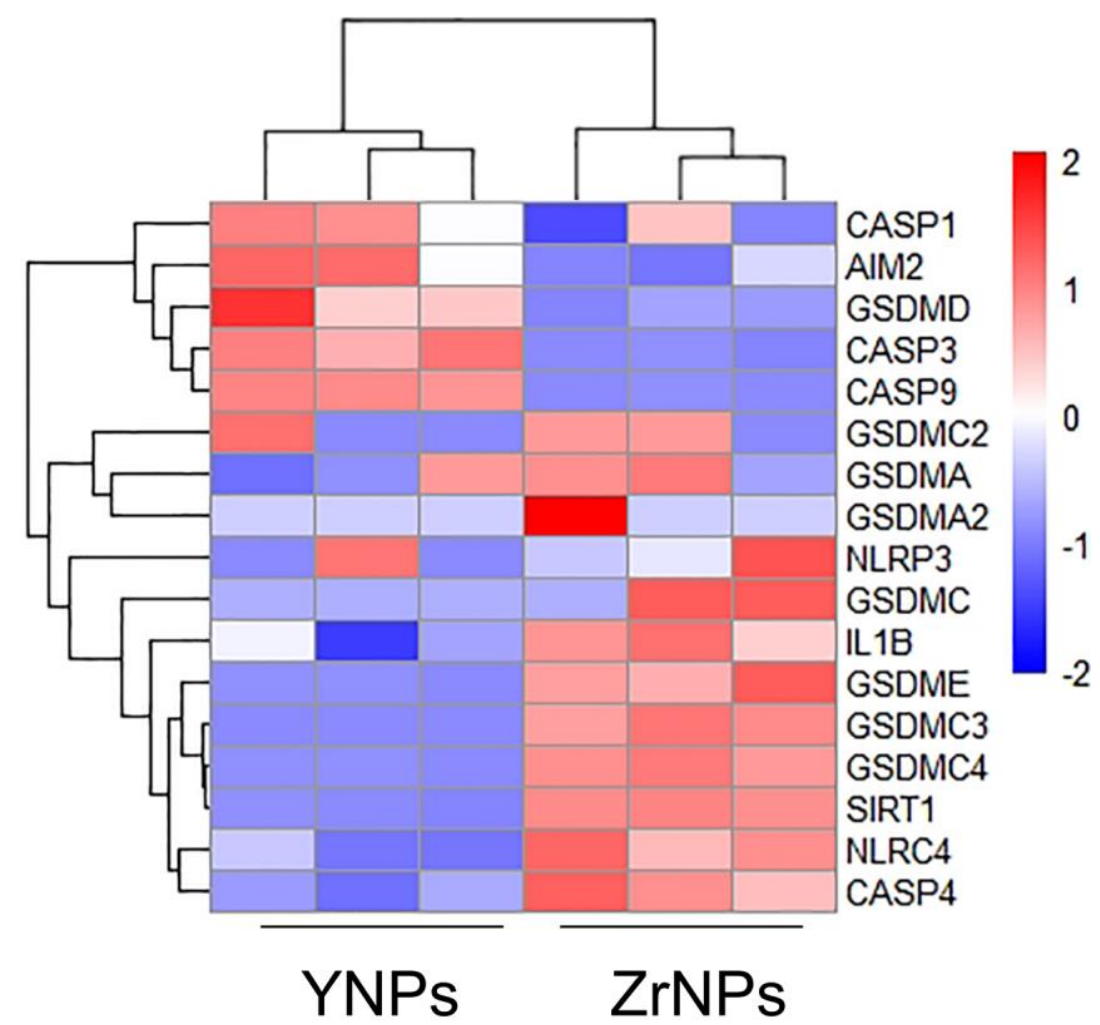

Figure S25. Differential gene expression heat maps of identified genes involved in pyroptosis in 4T1 cells treated with ZrNPs or YNPs. 


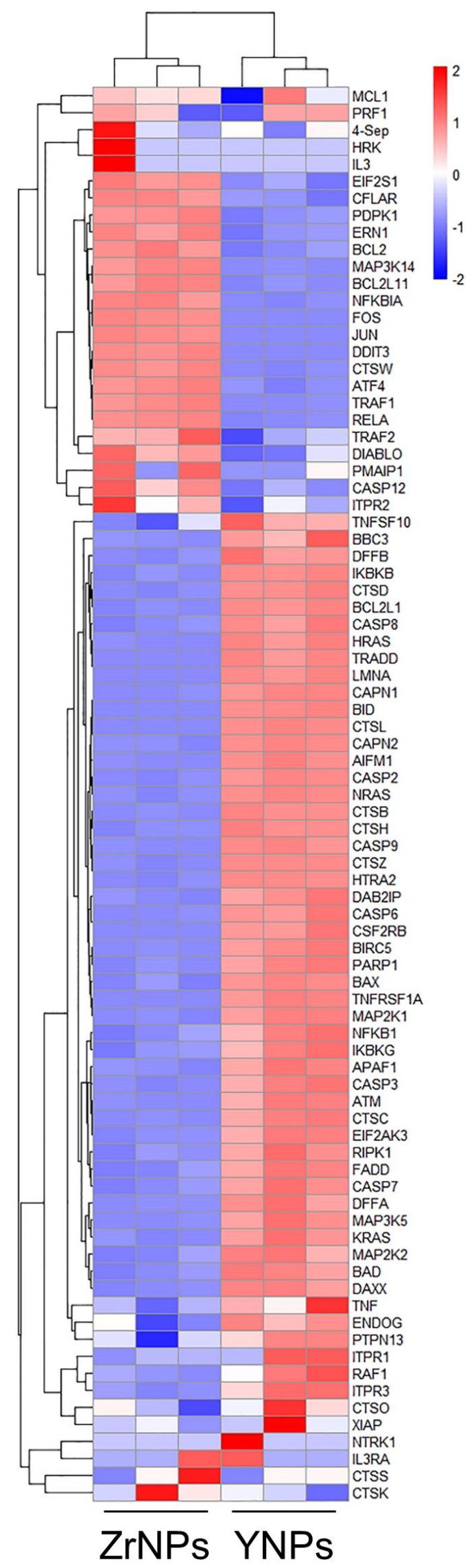

Figure S26. Differential gene expression heat maps of identified genes involved in apoptosis in 4T1 cells treated with ZrNPs or YNPs. 


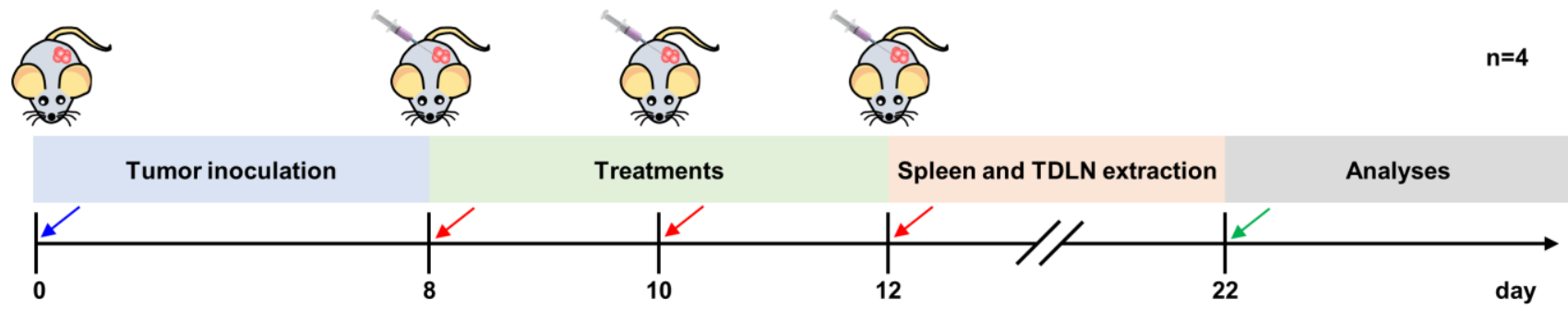

Figure S27. Experimental procedure for DCs and T cells measurements in spleen and tumor-draining lymph node (TDLN). 4T1 tumor-bearing BALB/c mice were randomly allocated into 3 groups ( $n=4)$, which were injected with three intratumor injections of (1) DMSO; (2) YNPs; (3) ZrNPs on day 8, 10, 12 (the day of the tumor inoculation is marked as day 0), respectively. The mice were sacrificed on day 22 and the single cell suspensions of spleen and TDLN were obtained.
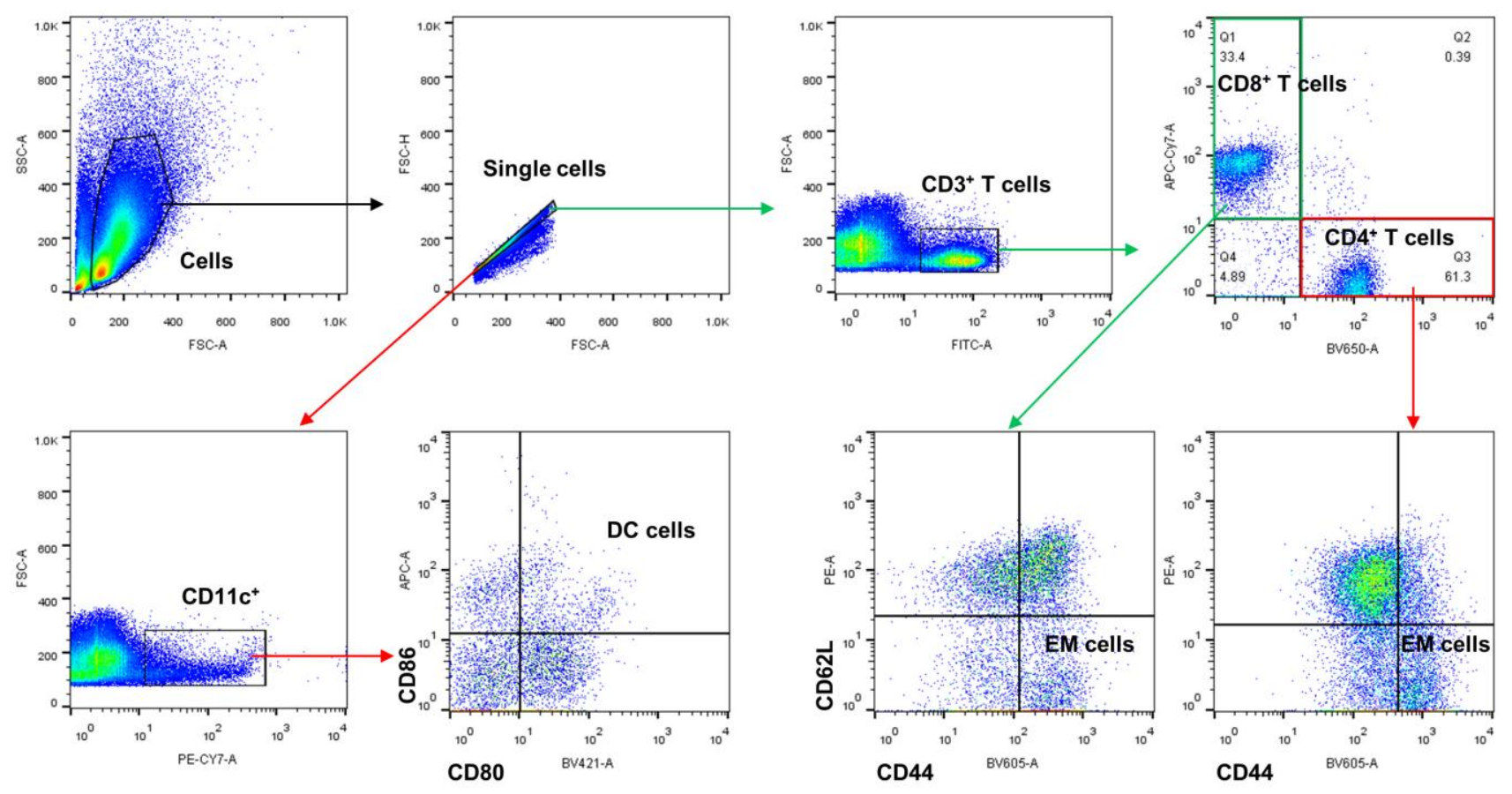

Figure S28. Schematic diagram of cell sorting process for analysis of immune cells in splenocytes.

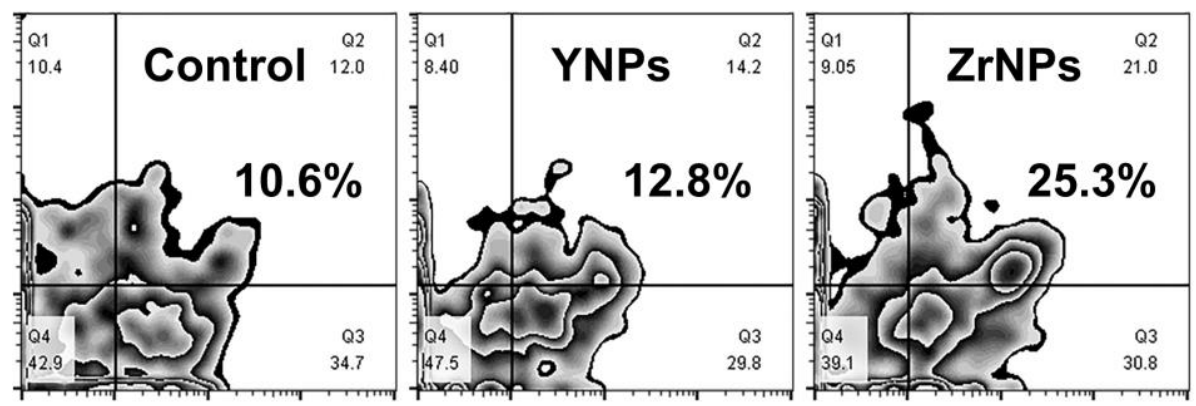

Figure S29. Flow cytometric analyses of the populations of dendritic cells (DCs) in splenocytes. 
a
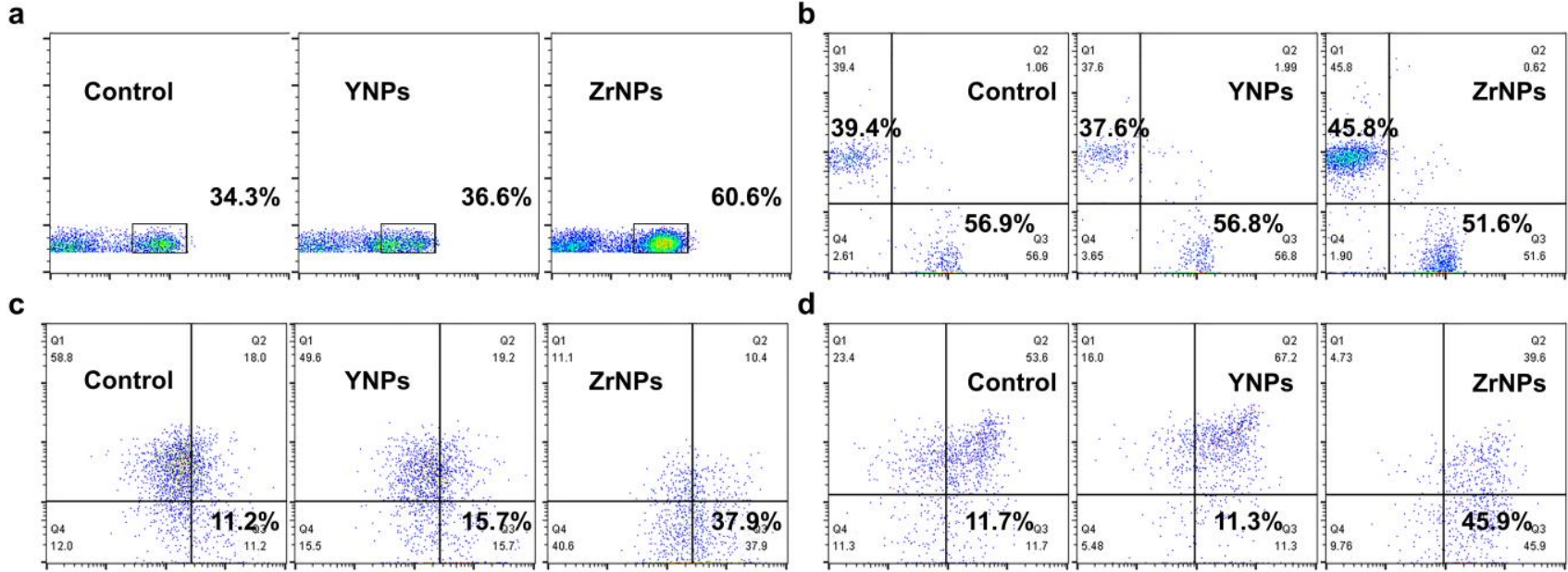

e

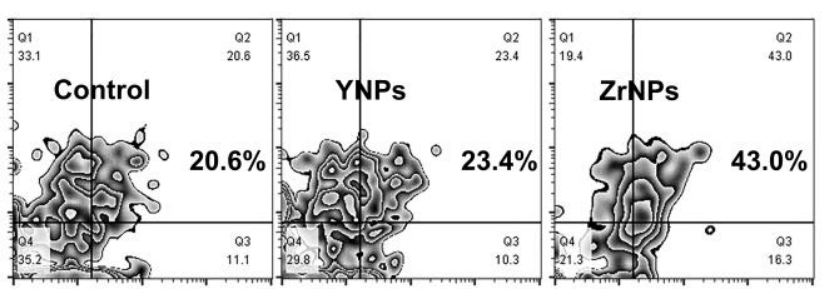

Figure S30. Flow cytometric analyses of the populations of (a) $\mathrm{CD} 3^{+} \mathrm{T}$ cells, (b) $\mathrm{CD} 4^{+}$and $\mathrm{CD} 8^{+} \mathrm{T}$ cells, (c) effector-memory (EM) cells in $\mathrm{CD}^{+}$cells, (d) EM cells in $\mathrm{CD} 8^{+}$cells and (e) DCs in tumordraining lymph node (TDLN) of mice.
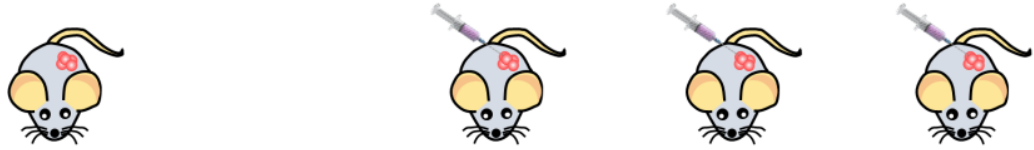

$n=6$

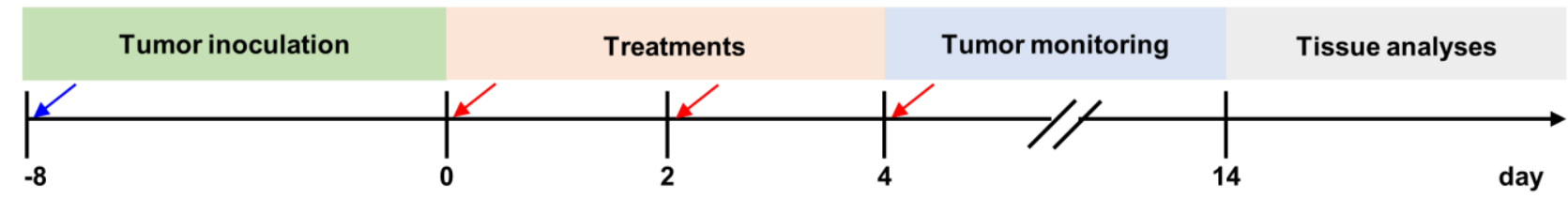

Figure S31. Treatment schedule of 4T1 tumor-bearing mice treated with different formulations. 4T1 tumor-bearing BALB/c mice were randomly allocated into 3 groups $(n=6)$, which were injected with three intratumor injections of (1) DMSO; (2) YNPs; (3) ZrNPs on day 0, 2, 4, respectively. The tumor sizes were measured every 2 days and body weights were recorded at the same time. On day 14, all of mice were sacrificed and the tumors were collected for staining. 


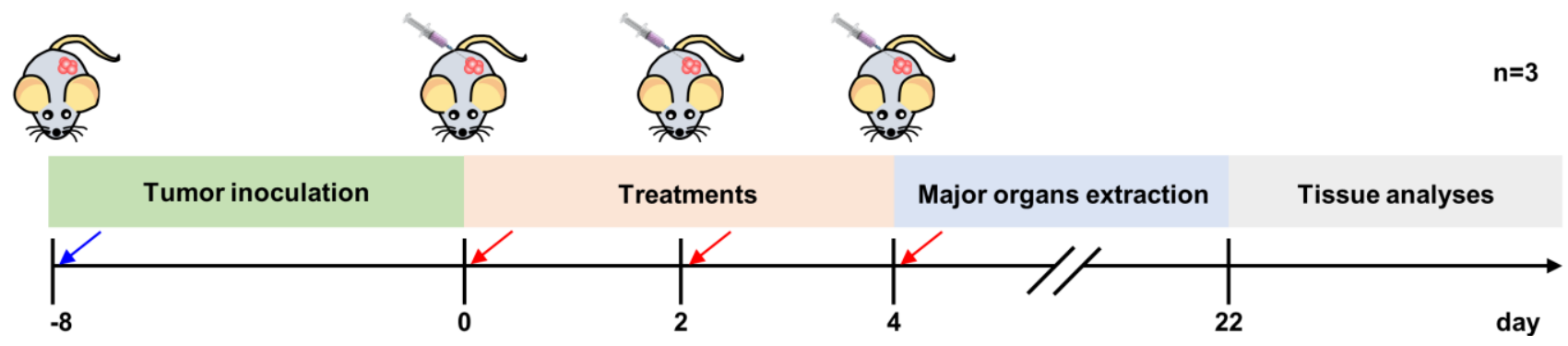

Figure S32. Therapeutic schedule for inhibition of tumor metastasis. 4T1 tumor-bearing BALB/c mice were randomly allocated into 3 groups $(n=3)$, which were injected with three intratumor injections of (1) DMSO; (2) YNPs; (3) ZrNPs on day 0, 2, 4, respectively. On day 22, all the mice were sacrificed. Major organs including heart, liver, spleen, lung and kidney were surgical removed and collected for H\&E analyses.

a

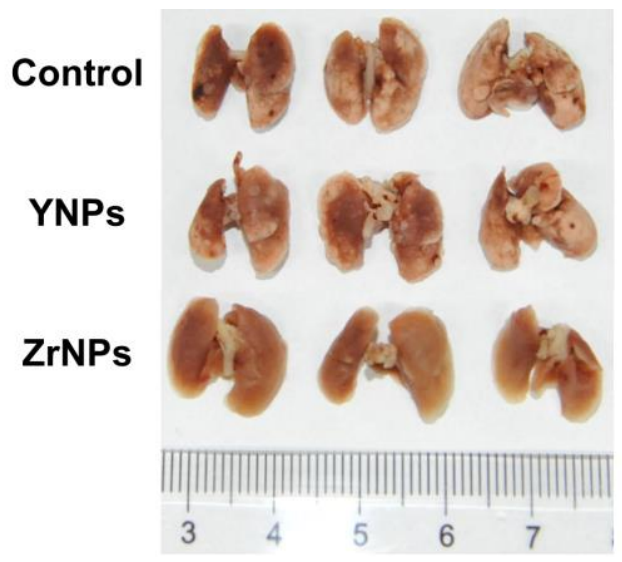

b

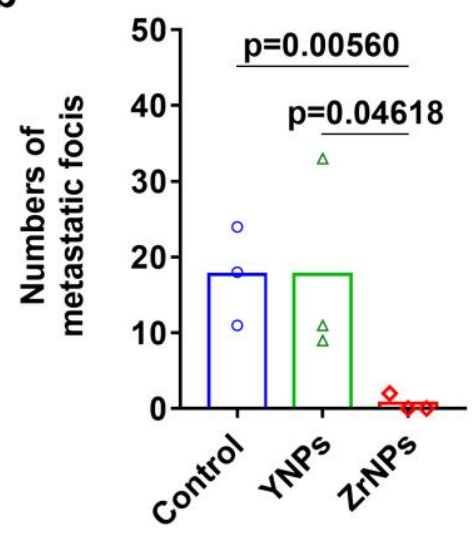

Figure S33. (a) The digital photographs of excised lungs. (b) Numbers of metastatic focis in excised lungs.

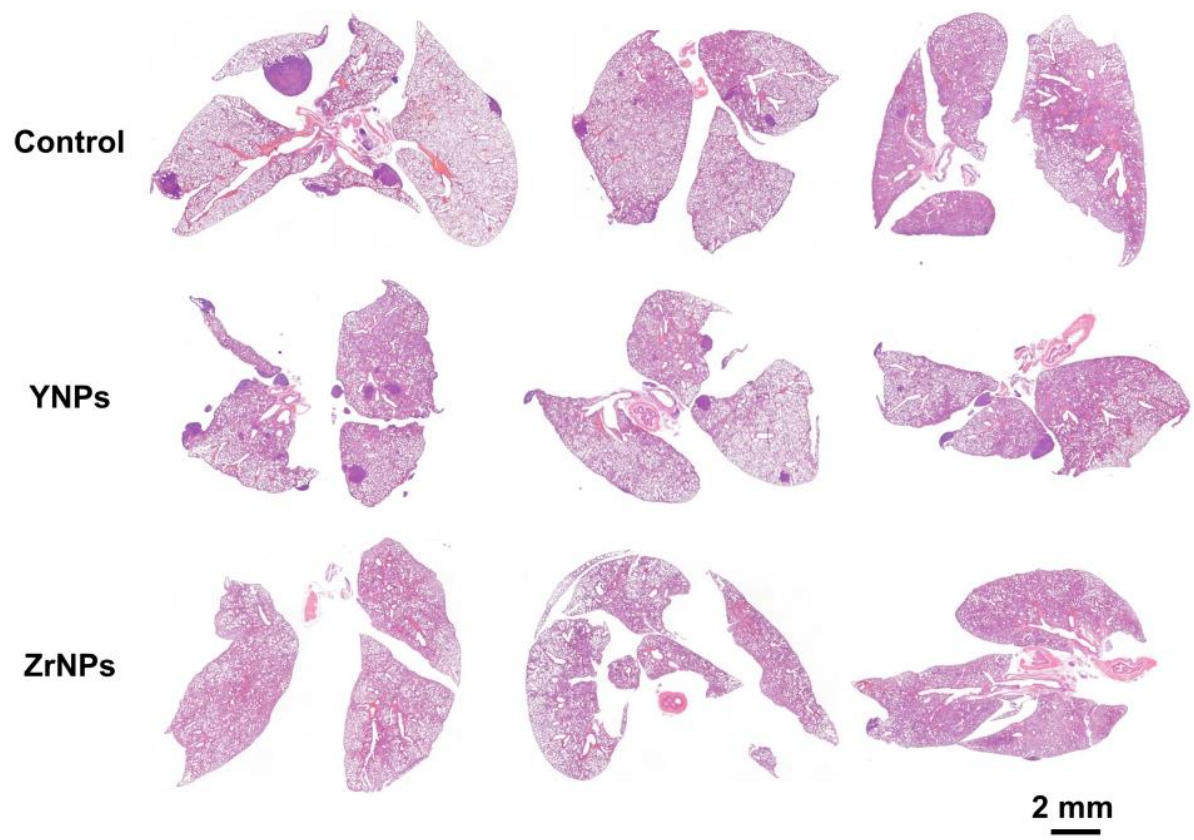

Figure S34. Hematoxylin and eosin (H\&E) staining of lungs in different groups. 


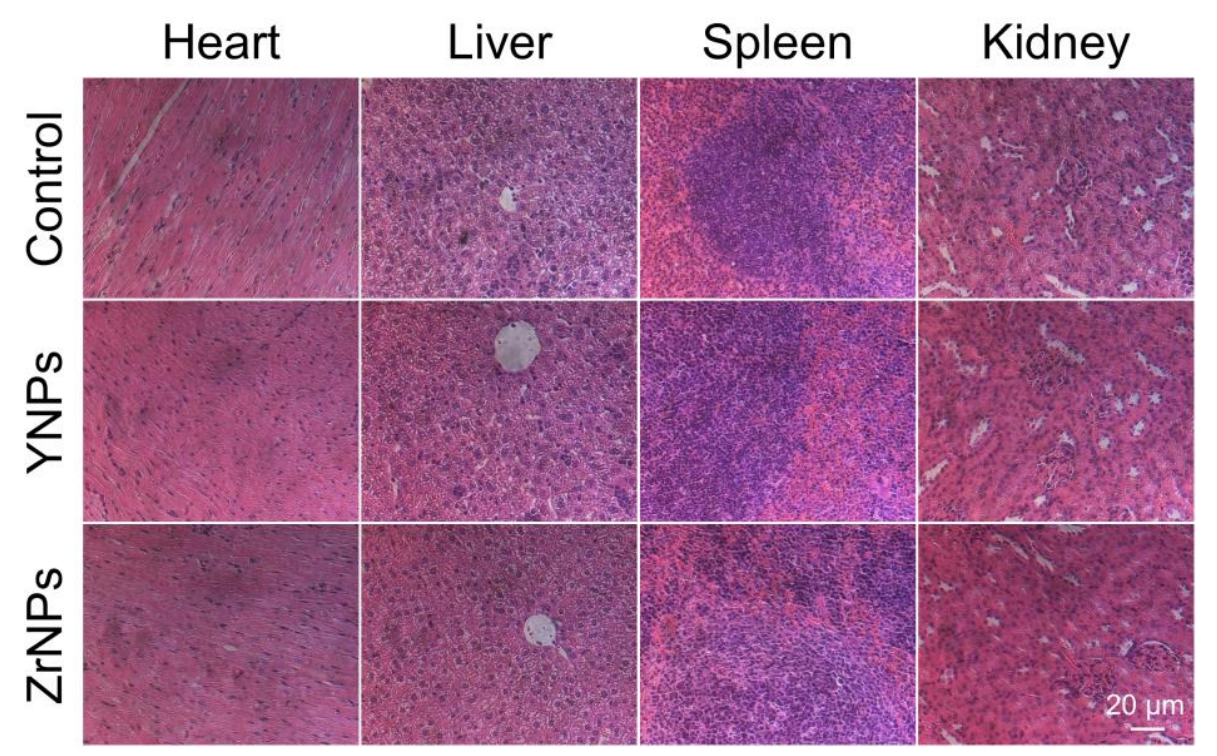

Figure S35. H\&E-stained images of major organs, including heart, liver, spleen and kidney.

\section{References}

[1] B. Ding, S. Shao, C. Yu, B. Teng, M. Wang, Z. Cheng, K.-L. Wong, P. a. Ma, J. Lin, Adv. Mater. 2018, 30, 1802479.

[2] J. Zhou, Q. Liu, W. Feng, Y. Sun, F. Li, Chem. Rev. 2015, 115, 395. 